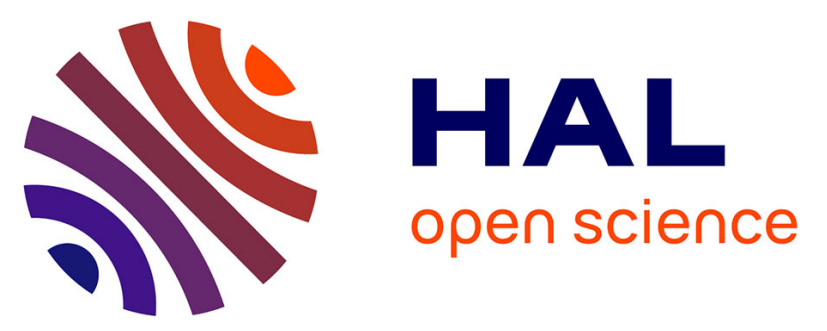

\title{
Investigation of Capitella spp. symbionts in the context of varying anthropic pressures: First occurrence of a transient advantageous epibiosis with the giant bacteria Thiomargarita sp. to survive seasonal increases of sulfides in sediments
}

Stéphane Hourdez, Céline Boidin-Wichlacz, Didier Jollivet, François Massol, Maria Claudia Rayol, Renato Bruno, Daniela Zeppilli, Frédéric Thomas, Ludovic Lesven, Gabriel Billon, et al.

\section{To cite this version:}

Stéphane Hourdez, Céline Boidin-Wichlacz, Didier Jollivet, François Massol, Maria Claudia Rayol, et al.. Investigation of Capitella spp. symbionts in the context of varying anthropic pressures: First occurrence of a transient advantageous epibiosis with the giant bacteria Thiomargarita sp. to survive seasonal increases of sulfides in sediments. Science of the Total Environment, 2021, 798, pp.149149. 10.1016/j.scitotenv.2021.149149 . hal-03312901

\section{HAL Id: hal-03312901 \\ https://hal.science/hal-03312901}

Submitted on 3 Aug 2021

HAL is a multi-disciplinary open access archive for the deposit and dissemination of scientific research documents, whether they are published or not. The documents may come from teaching and research institutions in France or abroad, or from public or private research centers.
L'archive ouverte pluridisciplinaire HAL, est destinée au dépôt et à la diffusion de documents scientifiques de niveau recherche, publiés ou non, émanant des établissements d'enseignement et de recherche français ou étrangers, des laboratoires publics ou privés.

\section{(1) (1) $\$$}

Distributed under a Creative Commons Attribution - NonCommercial - NoDerivatives 44.0 
Investigation of Capitella spp. symbionts in the context of varying anthropic pressures: First occurrence of a transient advantageous epibiosis with the giant bacteria Thiomargarita sp. to survive seasonal increases of sulfides in sediments

Stéphane Hourdez ${ }^{1, \delta}$, Céline Boidin-Wichlacz ${ }^{2,3, \delta}$, Didier Jollivet ${ }^{4}$, François Massol ${ }^{2,3}$, Maria Claudia Rayol ${ }^{5}$, Renato Bruno ${ }^{2,3}$, Daniela Zeppilli ${ }^{6}$, Frédéric Thomas ${ }^{7}$, Ludovic Lesven ${ }^{8}$, Gabriel Billon ${ }^{8}$, Sébastien Duperron ${ }^{9}$, Aurélie Tasiemski ${ }^{2}, 3^{*}$

$\delta$ These authors equally contribute to this work

${ }^{1}$ Observatoire Océanologique de Banyuls-sur-Mer, UMR 8222 CNRS-SU, avenue Pierre Fabre, 66650 Banyuls-sur-Mer, France

2 Univ. Lille, CNRS, Inserm, CHU Lille, Institut Pasteur de Lille, U1019-UMR9017-CIIL-Centre d'Infection et d'Immunité de Lille, Lille, France

3 Univ. Lille, CNRS, UMR 8198 - Evo-Eco-Paleo, F-59000 Lille, France

4 Sorbonne Université, CNRS UMR 7144 'Adaptation et Diversité en Milieux Marins' (AD2M), Team 'Dynamique de la Diversité Marine' (DyDiv), Station biologique de Roscoff, Place G.

Teissier, 29680 Roscoff, France.

${ }^{5}$ Centro Interdisciplinar em Energia e Ambiente - CIEnAm, Universidade Federal da Bahia, 40170-115 Salvador, BA, Brazil

${ }^{6}$ IFREMER, Centre Brest, REM/EEP/LEP, ZI de la Pointe du Diable, CS10070, 29280, Plouzané, France

${ }^{7}$ CREEC/CREES, UMR IRD-Université de Montpellier, Montpellier, France

${ }^{8}$ Univ. Lille, CNRS, UMR 8516 - LASIRE, Laboratoire Avancé de Spectroscopie pour les Interactions, la Réactivité et l'Environnement F-59000 Lille, France

${ }^{9}$ Muséum National d'Histoire Naturelle, CNRS UMR7245 Mécanismes de Communication et Adaptation des Micro-organismes, 12 rue Buffon, 75005 Paris, France.

* Correspondence to Aurélie Tasiemski : Center for Infection \& Immunity of Lille (CIIL), CGIM Team, Inserm U1019, CNRS UMR9017, Institut Pasteur de Lille, Bâtiment IBL,1 rue du Professeur Calmette, CS 50447, F-59021 Lille Cedex, France ; Email : aurelie.tasiemski@univlille.fr; Phone : 33(0)3.20.87.12.03 




\section{Worm's survival to sulfides}

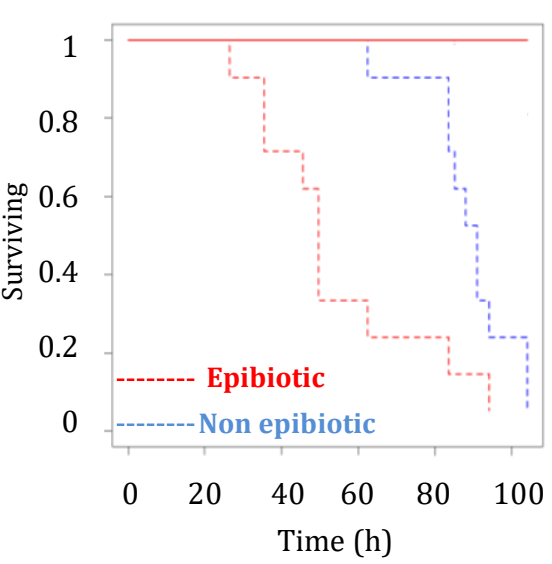




\section{Highlights}

- Local sediment geochemistry and diversity of symbionts associated to a common coastal worm are compared between specimens from an anthropized versus a non-anthropized site

- A peculiar development of a transient epibiosis with the giant sulfur oxidizing bacteria Thiomargarita spp was observed in Capitella spp. exposed to high level of sulfides

- The transient epibiosis allows the worms to survive toxic levels of sulfides during the summer

- This is the first evidence of an adaptive advantage of a facultative ectosymbiosis to face changing habitats 


\section{Abstract}

2 Capitella spp. is considered as an important ecological indicator of eutrophication due to

3 its high densities in organic-rich, reduced, and sometimes polluted coastal ecosystems. We

4 investigated whether such ability to cope with adverse ecological contexts might be a

5 response to the microorganisms these worms are associated with. In populations from the

6 French Atlantic coast (Roscoff, Brittany), we observed an epibiotic association covering the

7 tegument of $20-30 \%$ specimens from an anthropized site while individuals from a

8 reference, non-anthropized site were devoid of any visible epibionts. Using RNAseq,

9 molecular and microscopic analyses, we described and compared the microbial communities associated with the epibiotic versus the non-epibiotic specimens at both

11 locations. Interestingly, data showed that the epibiosis is characterized by sulfur-oxidizing

12 bacteria amongst which the giant bacterium Thiomargarita sp., to date only described in 13 deep sea habitats. Survey of Capitella combined with the geochemical analysis of their 14 sediment revealed that epibiotic specimens are always found in muds with the highest concentration of sulfides, mostly during the summer. Concomitantly, tolerance tests demonstrated that the acquisition of epibionts increased survival against toxic level of sulfides. Overall, the present data highlight for the first time a peculiar plastic adaptation to seasonal variations of the habitat based on a transcient epibiosis allowing a coastal species to survive temporary harsher conditions.

\section{INTRODUCTION}

21 The past decades have seen an increasing number of studies with the aim of characterizing

22 the biology of bacterial symbionts in a wide variety of invertebrates and plants, as well as

23 their role on community structure and ecosystem functioning (Brooks et al., 2017; Carrier

24 and Reitzel, 2017; Ferrari and Vavre, 2011; Gilbert et al., 2015; Moran and Wernegreen, 25 2000). It is now widely admitted that symbiotic associations can be responsible for some 
of the most noticeable changes in phenotypes, as they constitute a low-cost source of evolutionary innovation for their host (Margulis, 1991). The very short generation time of associated microorganisms could allow a faster acclimatization of the host to changing environments than the fixation of favorable alleles in the host genome, and therefore accelerate the acquisition of new phenotypes more adapted to novel ecological conditions. For instance, it is now well established that diagnostic traits of numerous symbiotic species are in fact a response to the microorganisms they are associated with (McFall-Ngai, 2008; McFall-Ngai et al., 2013). Symbioses have been shown to affect adaptive traits, from trophic niche (Kohl et al., 2014) to temperature dependence (Morsy et al., 2010), salinity tolerance (Nougué et al., 2015), resistance to oxidative stress (Richier et al., 2005), or resistance against pathogens (Kaltenpoth and Engl, 2014; Tasiemski et al., 2015) that may have an early effect during organism development (Gasnier-Fauchet et al., 1986; Gilbert et al., 2015). Consequently, understanding the adaptation of marine species to changing environments requires the further exploration of how the environment impacts the hostsymbiont associations and their evolution for either endo- or ecto-symbioses (epibiosis). Until now, the symbiotic microflora of marine animals was often considered as a random consortium (McFall-Ngai, 2008). However, multiple lines of evidence show that this microflora corresponds in fact to a highly specialized microbial community forming a specific and stable symbiosis with its host, with dedicated roles. The discovery of the association of chemoautotrophic bacteria with the deep-sea hydrothermal vent tube worm, Riftia pachyptila revolutionized our view about the morphological and physiological impact of bacteria on the host (Bright and Lallier, 2010; Cavanaugh et al., 1981; Felbeck, 1981). Chemoautotrophic bacteria use sulfur compounds, particularly hydrogen sulfide, a chemical highly toxic to most known organisms, to produce organic material through the process of chemosynthesis. Interestingly, $R$. pachyptila develops from a non-symbiotic 
trochophore larva, which enters juvenile development, becoming sessile, and subsequently acquiring symbiotic bacteria through skin infection. After chemoautotrophic bacteria are established in the midgut of the juveniles, it undergoes substantial remodelling and enlargement to become the trophosome, while the remainder of the digestive tract fully disappears in adults (Stewart and Cavanaugh, 2006). Lacking a mouth and a gut and being unable to obtain organic compounds by diffusion, adults gain the latter via sulfur oxidation$\mathrm{CO}_{2}$ fixation driven by the endosymbionts confined into peculiar cells (namely bacteriocytes) of the trophosome. The tubeworm depends completely on the chemoautotrophic bacteria for the byproducts of their carbon fixation cycles needed for its growth. Reciprocally, endosymbionts rely on $R$. pachyptila for the assimilation of nutrients needed for the array of metabolic reactions they employ (Bright and Lallier, 2010). Soon after this first description of chemoautotrophic symbiosis, additional thiotrophic symbioses were described at oxic-anoxic interfaces of more accessible coastal shallowwaters also recognized as chemosynthetic based ecosystems (Dubilier et al., 2008; Petersen et al., 2011; Stewart et al., 2005). Gutless oligochaetes' (annelids) and stilbonematids' (nematodes) symbioses are among them and constitute a remarkably well-described and interesting mode of nutrition (Bulgheresi, 2016; Dubilier et al., 2006; Polz et al., 1992). More recently, the nematode Metoncholaimus albidus, reported in the Roscoff Harbor (Brittany, France), has also been shown to be associated with distinct microbial communities known to be involved in sulfur metabolism (Bellec et al., 2019). Marine worms belonging to the genus Capitella represent the most common component species of benthic communities in organically enriched ecosystems throughout the world

73 (Kitamori, 1975; Pearson and Rosenberg, 1978; Reish, 1979). This so-called sediment "black zone" - previously considered to be azoic - is characterized by strongly reducing, micro- to anaerobic conditions with high concentrations of reduced sulfur species like 
dissolved sulfides and polysulfides, thiols... and sulfide precipitates such as MeS (where Me can be $\mathrm{Fe}, \mathrm{Pb}, \mathrm{Zn}, \mathrm{Cd} . .$. ), $\mathrm{Fe}_{3} \mathrm{~S}_{4}$ and $\mathrm{FeS}_{2}$ (Wood, 1992). Differential tolerance to sulfide has been observed between sibling species of Capitella, leading to the hypothesis that these ecophysiological differences were genetically fixed and that sulfidic environments could have been the driving force of such species diversification (Gamenick et al., 1998). The tolerance to sulfides in Capitella sp1 from North America (subsequently identified as Capitella teleta (Blake et al., 2009)) was evaluated through experimental exposure of the annelids to $\mathrm{H}_{2} \mathrm{~S}$ under laboratory conditions. Sulfide concentrations up to $2 \mathrm{mM}$ were considered as a cue for Capitella sp1 larval settlement (Cuomo, 1985) whereas those exceeding $10 \mathrm{mM}$ were detrimental to their survival (Dubilier et al 1988). The presence of sulfides up to $7 \mathrm{mM}$ was also shown to favor the burrowing activity of adults thus stimulating the respiratory activities of the bacteria associated with the mucus-lined burrow of the worm in soft agar microcosm (Wada et al., 2006). This was coupled with an enhanced growth and survival rates of the adults observed in sediments supplied with sulfides for 6 weeks (Tsutsumi et al., 2001). Consequently, Capitella species does not seem to favor organically enriched sediment with sulfides but rather prefers the environments that sulfides provide. As mentioned before, hydrogen sulfide can be exploited for the chemosynthesis of organic matter by chemoautotrophic bacteria. Capitella species are not gutless worms and an examination of Capitella sp. I for the presence of enzymes commonly associated with chemoautotrophic bacteria $\sim 40$ years ago has led to the conclusion by the authors that adults were not associated with chemoautotrophic symbionts (Cavanaugh, 1983; Cuomo, 1985).

The main purpose of this paper was to explore both the microhabitat and microbial diversities associated with the complex of Capitella species recently identified as "Capitella spp. from the English Channel" (Boidin-Wichlacz et al., Under review) to first report 
101 whether such host-symbiont interactions (notably with chemoautotrophic bacteria) exist 102 and to evaluate secondarily whether changing environmental conditions, and especially 103 sulfides can affect these associations and the worm tolerance to this chemical.

104 For this end, Capitella specimens collected from two sites with differing levels of anthropic 105 influence and sulfides were compared. Biogeochemical characteristics of the sites were 106 documented, and microbial communities associated with specimens of Capitella sp. were 107 assessed using a RNASeq-based approach. Finally, the cost versus benefit of the transient

108 association with sulfur-oxidizing ectosymbionts was studied in animals exposed to lethal 109 doses of sulfides.

111 1. MATERIALS AND METHODS

\subsection{Specimen collection}

113 Sediment and Capitella specimens were collected together at two different sites: the

114 Roscoff Harbor and Le Laber near Roscoff (Brittany, France). For the « Tolerance tests to 115 experimental exposure to sulfides" worms were only sampled at the Roscoff Harbor.

116 A map with the GPS coordinates is presented in Fig. 1. The sampling dates and locations for 117 each experiment as well as the number of collected worms are detailed in the 118 supplementary data (Table S1). Capitella spp. were collected at low tide. At both locations, 119 Capitella individuals were abundant, representing the most dominant species in the Roscoff 120 Harbor, and with abundance similar to that of oligochaetes in the nearby site Le Laber. The 121 sediment was sieved on a $500 \mu \mathrm{m}$ mesh in the field and animals were brought back to the 122 laboratory for sorting under a dissecting microscope.

\section{1.2. Sediments}


124 The methods used to determine the "Total metal concentrations", the "Carbon and nitrogen contents", the "AVS, CRS and HCl-extractable metals" and the "Granulometry" of the sediments are provided as supplementary data.

Sampling and pretreatments - Sediments of the two study sites were characterized in terms of trace metals concentrations (total metals and metals extracted with $1 \mathrm{M} \mathrm{HCl}$ ), reduced sulfur species content (AVS: Acid Volatile Sulfides and CRS: Chromium Reducible Sulfur), dissolved sulfides and additional environmental parameters. Sediments were collected using a $5 \mathrm{~cm}$ long (for the top $0-5-\mathrm{cm}$ surface layer of sediment) or along cores of $35 \mathrm{~cm}$ long (for sediment profiles) using Perspex tubes (internal diameter: $7.5 \mathrm{~cm}$ ). Cores sampled with the Perspex tubes were put into a glove box, previously flushed with nitrogen, and sliced every $1 \mathrm{~cm}$ at both sites. Each sediment sample was then stored under nitrogen untreated in a plastic bag at $-18^{\circ} \mathrm{C}$ prior to perform AVS, CRS and metal analyses. A slice of each core was also dried to measure granulometry and total carbon and nitrogen contents. Additional sediment cores were sampled for exposure to DGT (Diffusive Gradients in Thin films) - AgI passive samplers used for dissolved sulfide determination.

Enrichment factor and toxicity index calculation - The enrichment factor (EF) normalized towards aluminum (Al) has been used to compare the level of metal pollution between our sediment samples. This factor is defined as follows:

$$
E F=\frac{\frac{[\mathrm{Me}]_{\text {sample }}}{[\mathrm{Al}]_{\text {sample }}}}{\frac{[\mathrm{Me}]_{\text {reference }}}{[\mathrm{Al}]_{\text {reference }}}}
$$

144 Where $[\mathrm{Me}]_{\text {sample }}$ and $[\mathrm{Me}]_{\text {reference }}$ are the concentrations of metal $(\mathrm{Me}: \mathrm{Cd}, \mathrm{Co}, \mathrm{Cu}, \mathrm{Ni}, \mathrm{Pb}$ or $145 \mathrm{Zn}$ ) in our samples and in the reference material, respectively (Audry et al., 2004; Davide 146 et al., 2003). To avoid using average world values for the reference material that do not 
reflect the local geology of the area studied, reference geochemical background values from pristine loess deep horizons in the North of France (Boulogne, Gravelines and Authie) has

149 been considered (Sterckeman et al., 2006).

150 The toxicity index (TI) was calculated as the ratio SEM/AVS to predict metal sediment

151 toxicity towards benthic invertebrate species (Ankley et al., 1993). Its relevance has been 152 demonstrated via toxicity tests on several benthic organisms (notably the polychaetes 153 Capitella capitata and Neanthes arenaceodentata), in natura or through experimental 154 exposure to contaminants (Lee et al., 2000). For each sample, the TI has been calculated, 155 according to the following relation: $\mathrm{TI}=\log ([\mathrm{SEM}] /[\mathrm{AVS}])$ (Ankley et al., 1993). Previous 156 studies have shown that sediments with $\mathrm{TI}>0$ are toxic for animals whereas sediments 157 with TI $\leq 0$ are not (Hansen et al., 2005)., AVS and SEM data of the 5 first $\mathrm{cm}$ of the sediment 158 were used to calculate the TI values for both study sites over a period of time from 28 of 159 July to 8 of December 2015.

160 Dissolved Sulfides - Dissolved sulfides were measured using DGT-AgI probes (Gao et al., 161 2009). Briefly, dissolved sulfides were measured from a coloration which turns from white 162 to black when forming $\mathrm{Ag}_{2} \mathrm{~S}$ with sulfides after diffusing from pore-water through an 163 acetate cellulose filter $(0.45 \mu \mathrm{m}$ pore size $)$ into a polyacrylamide gel containing the AgI 164 precipitate. After a known exposure time of the filter in pore-water samples, the precipitate 165 is scanned using a commercial flatbed scanner and color intensity is then digitized and 166 calibrated to calculate the concentrations initially present (Lourino-Cabana et al., 2014; 167 Teasdale et al., 1999). Calibration of the DGT-AgI probes in standard sulfide solutions were 168 performed using the same conditions.

169 1.3. Microbial communities associated with the worms

170 worms sampling -For the RNAseq, animals collected in 2013, were checked for

171 filamentous epibionts under the microscope and separated into three groups: 1/ non 
epibiotic animals from the Le Laber 2/ non epibiotic animals from the Roscoff Harbor and 3/ epibiotic animals from the Roscoff Harbor (Fig 2B). For each group, 30 individuals were placed in RNA-later. At the time of sampling for transcriptome sequencing, Capitella

175 covered by epibionts were only found at the Roscoff Harbor site; no epibiotic individuals were found in Le Laber. For the morphological analyses, five specimens of each group were 177 fixed in glutaraldehyde $2.5 \%$ for electron microscopy and five were fixed in 178 paraformaldehyde 4\%, for fluorescence in situ hybridization in 2013 and in 2014.

179 Seasonal survey of associations with Thiomargarita on Capitella spp - From March to 180 December 2015, samples were collected at two-week intervals from both Le Laber and the 181 Roscoff Harbor sites (19 sampling events per site). Each individual worm was then 182 preserved in $85 \%$ ethanol. Fifty-two individuals were used for the genetic analysis (see 183 below) and the remaining worms were later observed individually under a dissection 184 microscope to check for presence of epibiotic microorganisms and measure the width of 185 the body at the fifth setiger (Pardo et al., 2010). In total, 5900 worms were sampled (with 186 150-160 worms collected at each sampling event at each site). To obtain a better estimation 187 of the association prevalence among the worms, the association (presence/absence) of 188 large epibiotic microorganisms was modeled as a Bernoulli random variable through a 189 generalized linear model (GLM) with binomial error and logit link between the explanatory 190 variables and their effect on the association probability. We built 166 different GLM based 191 on the "complete model", which incorporated the effects of site (Le Laber vs. Roscoff 192 Harbor), worm size and Julian date (number of days since last change of year). The other 193165 models were obtained as the sub-models nested within the complete one (i.e. models 194 lacking one or more explanatory variables or interactions thereof). The goodness-of-fit of 195 each model and its corrected Akaike Information Criterion (AICc) were computed and 196 models were ranked from best to worst following increasing values of AICc. To obtain a 
more robust estimation of model predictions, model averaging procedures were used based on the Akaike weight of each model (Burnham et al., 2011). For all these statistical analyses, R (v 3.2.3) was used with package 'fields' to make the heatmaps and package ‘MuMIn’ for automated model goodness-of-fit comparisons and model averaging.

\subsection{Morphological observations of associated microorganisms}

Optical microscopy - For each sample of Le Laber and the Roscoff Harbor, worms with and without large epibionts were examined alive or fixed (paraformaldehyde 4\%) using an optical microscope (Zeiss Axio Imager M2) and a stereomicroscope (Zeiss Stemi 305).

Electron microscopy of the epibiotic microflora - Specimens of the three groups (epibiotic from the Roscoff Harbor and non-epibiotic from the Roscoff Harbor or from Le Laber) fixed in $2.5 \%$ glutaraldehyde were dehydrated in a series of ethanol solutions of progressively 208 increasing concentrations (75-100\%), critical-point-dried with a Balzers SCD 30 209 (temperature $37^{\circ} \mathrm{C}$ and pressure $70 \mathrm{~kg} \mathrm{~cm}^{-2}$ ), mounted on stubs, covered with a layer of $10-$ $20 \mathrm{~nm}$ of gold, and observed under the SEM using a JEOL JSM-840A Scanning Electron 211 Microscope at $20 \mathrm{kV}$ accelerating voltage.

212 Fluorescence in situ hybridization (FISH) of epibiotic microflora - FISH experiments 213 were performed using generalist probes targeting Eubacteria (EUB338), 214 Gammaproteobacteria (GAM42), and the probe NON338 (antisense of EUB338) as a 215 negative control \{Amann, 1990 \#159\}. All hybridizations were conducted using 30\% 216 formamide at $46^{\circ} \mathrm{C}$ for 3 hours, followed by a 15 minutes rinse in appropriate buffer using 217 the protocol described in (Duperron, 2017). FISH hybridizations were performed on whole 218 specimens of Capitella fixed in paraformaldehyde $4 \%$ to visualize epibionts, as well as on $2198 \mu \mathrm{m}$-thick cross sections of specimens that were previously embedded in Steedman Wax 220 as described in (Duperron et al., 2008), using DAPI as a background stain. Hybridized 221 samples were visualized under a BX61 epifluorescence microscope (Olympus, Japan). 


\section{RNAseq sequencing}

RNA extraction and sequencing - To assess microorganisms co-occurring with Capitella,

RNAs from the three groups (see worm sampling) were extracted and sequenced to obtain

transcriptomes representative of eukaryotes and prokaryotes associated with the worms.

227 The total RNAs of each group were extracted with the TRI-Reagent solution (Sigma), 228 following the manufacturer's protocol. The RNAs were re-suspended in DEPC-treated water and the quality and quantity were evaluated on a Nanodrop. An Illumina library was prepared for each of the three groups. Each library was sequenced on one lane of HiSeq 2000 (100 million clusters, 2x100 bases paired-end). RNAseq sequencing was performed at Genoscreen (Lille, France).

233 Assembly and determination of the abundance of assembled contigs -The analyses were

234 all carried out in the Galaxy environment and the computing power was provided by the ABiMS platform (Station Biologique de Roscoff, France). The 100-bp paired-ends reads for each group were first filtered for quality with Prinseq-lite, and the pairs of sequences of sufficient quality were established (GetPairs) (Schmieder and Edwards, 2011). The

238 ribosomal sequences were separated from the remaining sequences based on similarity 239 with a rRNA database (riboPicker) (Schmieder et al., 2011). These reads targeted rRNA of 240 both the hosts and the associated microfauna (typically about 25 million paired reads per 241 library) were then assembled with Trinity after normalization to reduce the size of the 242 dataset. This was performed on the three libraries and the resulting contigs were 243 concatenated. Redundancy was removed with CAP3 (Huang and Madan, 1999). The final 244 assembly of rRNA sequences was then used as a reference for quantification of the contigs 245 for each habitat-driven library of worms with RSEM (Li and Dewey, 2011). The results were 246 normalized for the size of the contigs, and the sequencing effort, and are expressed in 
247 Fragment Per Kilobase of transcript per Million reads of sequencing (FPKM). The closest 248 sequences in GenBank were identified by Blastn and the identifier recovered for all contigs 249 (Altschul et al., 1997).

\subsection{Molecular identification of the large epibionts using 16S rRNA}

251 Clone libraries of the 16SrRNA-encoding gene were built from 4 specimens, 2 displaying 252 and 2 devoid of large epibionts using standard bacterial 16SrRNA primers 8F and 1492R 253 as described in (Duperron et al., 2005). Among the distinct bacterial sequences identified, 254 one found only in specimens displaying epibionts was used to design specific primers 255 targeting these epibionts (Forward 5'- GCTGGTCTGAGAGGACGAAC-3'; Reverse $3^{\prime}$ TTCATGGAGTCGAGTTGCAG-5) with the Primer3 Input software

257 (http://frodo.wi.mit.edu/cgi-bin/primer3/primer3www.cgi).

258 Large epibionts were also isolated from debris pellets after centrifuging each worm of the 2015 collection (at $4000 \mathrm{rpm}$ for $5 \mathrm{~min}$ ) in an ethanol solution as they immediately detach from Capitella in presence of ethanol. Microbial DNA was extracted using the NucleoSpin

261 Tissue kit for bacteria (Macherey-Nagel) according to the manufacturer's instructions, and 262 amplified with a GoTaq® G2 DNA Polymerase (Promega) using Thiomargarita-specific 263 primers. Reaction mixture for PCR amplification contained $10 \mu \mathrm{M}$ of each primer, $10 \mu \mathrm{M}$ of 264 each (dNTP), 1X Go Taq® Flexi buffer (Promega), and 5U of GoTaq G2 Flexi DNA 265 polymerase (Promega). The final volume was adjusted to $25 \mu \mathrm{l}$ with water. DNA 266 amplification was performed under the following conditions: (1) An initial denaturation 267 step at $95^{\circ} \mathrm{C}$ for 3 min without enzyme, followed by (2) a series of 39 cycles of denaturation 268 at $95^{\circ} \mathrm{C}$ for $45 \mathrm{~s}$, of annealing at $55^{\circ} \mathrm{C}$ for $45 \mathrm{~s}$, and elongation at $72^{\circ} \mathrm{C}$ for 1 min with the 269 enzyme, and (3) a final elongation step at $72^{\circ} \mathrm{C}$ for $7 \mathrm{~min}$. PCR products were purified with 270 the NucleoSpin ${ }^{\circledR}$ Gel and PCR Clean-up kit (Macherey-Nagel) and were then sequenced 271 according to the Sanger method on a 310 ABI prism (Applied Biosystems). 

et al., 2007). A $16 \mathrm{~S}$ rRNA dataset was built by collecting sequences available from Thiomargarita and related groups. Phylogenetic relationships were estimated based on maximum likelihood using a General Time Reversible (GTR) model and a 5-category discrete Gamma distribution of rates with invariants. Positions with gaps and missing data were not used, resulting in a 1107-bp dataset. Phylogenetic reconstructions were generated using the software MEGA 7 (Kumar et al., 2016).

\subsection{Genotyping of epibiotic and non-epibiotic Capitella individuals}

DNA extraction and barcoding - After the epibiont recovery, fifty-two Capitella collected

during our 2015 temporal survey (see before) in both Le Laber and the Roscoff Harbor were used entirely for DNA extraction using a NucleoSpin Tissue XS (Macherey-Nagel)

283 according to manufacturer's protocol. A $569 \mathrm{bp}$ fragment of the cytochrome oxidase subunit 1 (Cox-1) mitochondrial gene was then amplified using Capitella-specific primers CCACCACCAGTAGGATCAAA -3'. Amplifications were carried out with a GoTaq® G2 DNA Polymerase (Promega). Reaction mixture for PCR amplification contained $10 \mu \mathrm{M}$ of each primer, $10 \mu \mathrm{M}$ of each desoxynucleotide triphosphate (dNTP), 1X Go Taq ${ }^{\circledR}$ Flexi buffer (Promega), and 5U of GoTaq G2 Flexi DNA polymerase (Promega). The final volume was adjusted to $25 \mu \mathrm{l}$ with sterile water. DNA amplification was performed on a Thermocycler 291 (Eppendorf) with the following conditions: (1) an initial denaturation step at $95^{\circ} \mathrm{C}$ for 15 min without enzyme, followed by (2) a series of 39 cycles of denaturation at $95^{\circ} \mathrm{C}$ for $30 \mathrm{~s}$, 293 of annealing at $56^{\circ} \mathrm{C}$ for $30 \mathrm{~s}$, and elongation at $72^{\circ} \mathrm{C}$ for $1 \mathrm{~min}$ with the enzyme, and (3) a

294 final elongation step at $72^{\circ} \mathrm{C}$ for $5 \mathrm{~min}$. The PCR products were then visualized onto a $1.5 \%$ 295 agarose gel with ethidium bromide following electrophoresis at 100 volts for half an hour. PCR products were-then purified with nucleofast 96 PCR cleanup kit and then Sanger- 
sequenced on an ABI 3100 using BigDye (PerkinElmer) terminator chemistry following the manufacturer's protocol. (Applied Biosystems, Foster City, CA).

Sequence analysis - Chromatograms were checked manually using SeqScape V2.5. The sequence data were aligned manually with BioEdit v.7.2.5. Maximum likelihood tree reconstructions were performed on our subset of barcoded specimens and additional referenced sequences from Genbank using the software Mega7 following the HKY model of substitutions with the pairwise deletion option (Kumar et al., 2016) to check whether Capitella spp. populations found at Le Laber and at the Roscoff Harbor represent cryptic species.

\subsection{Tolerance tests to experimental exposure to sulfides}

Animals collected in July 2020 at the Roscoff Harbor were checked for filamentous epibionts under the microscope and then split into two groups: non-epibiotic Capitella (3 batches of 10 individuals each) and epibiotic Capitella (3 batches of 10 individuals each).

Each batch was placed in a petri dish $(35 \mathrm{~mm})$ containing $2 \mathrm{~mL}$ of artificial seawater (Instant

311 Ocean). The 3 "non epibiotic" batches and the 3 "epibiotic" batches were separately exposed to increasing concentrations of sulfides (batch $0 \mathrm{mM}, 1 \mathrm{mM}$ and $3 \mathrm{mM}$ of $\mathrm{Na}_{2} \mathrm{~S} 9 \mathrm{H}_{2} \mathrm{O}$

313 (SIGMA) in artificial seawater (Instant Ocean® Sea Salt) for 4 days in a moisture chamber 314 in the dark at $16^{\circ} \mathrm{C}$. Mortality was assessed every 3 hours, dead animals were counted and 315 immediately removed. The sulfide concentration was also measured and adjusted when 316 required at the same intervals by using the $\mathrm{N}$, N-dimethyl-p-phenylenediamine 317 colorimetric method (Walkley and Black, 2003).

318 Survivorship data were analyzed through Cox proportional hazard models (Andersen and 319 Gill, 1982), using the 'coxph' function within the 'survival' package in R programming 320 language (Jackson, 2016). All survival data were analyzed together (same mortality 321 baseline) for the sake of effect comparability. Mortality was assumed to depend on the 
322

323

324

325

326

327

328

329

330

331

332

333

334

335

336

337

338

339

phenotype of the worms (epibiotic and non-epibiotic) and the concentration of sulfides ( 0 , 2 and $3 \mathrm{mM}$ ). We used robust variance estimation (Horvitz-Thompson estimate) assuming correlation among individuals from the same batch (same experiment x same phenotype $\mathrm{x}$ same treatment).

\section{RESULTS}

\subsection{Geochemical characterization of sediments in both sites}

General parameters - Sediment granulometry was very similar for both sites (Fig. S1): silts $(2-63 \mu \mathrm{m})$ are the most abundant fraction $(40-50 \%)$, and their proportions increased toward the sediment-water interface. In the fine fraction, smaller than $63 \mu \mathrm{m}$, the amount of $\mathrm{Ca}, \mathrm{Fe}$ and $\mathrm{Al}$ were higher at the Roscoff Harbor than at Le Laber, suggesting that sandy particles, less reactive than clays, carbonates and iron oxides, were more frequent in sediments of Le Laber (Table 1). In the Roscoff Harbor, the layer with the highest proportion of silts extends to a depth of about $3 \mathrm{~cm}$ when compared with the site Le Laber (less than $2 \mathrm{~cm}$ depth). In this top layer, organic and inorganic carbon contents were greater at the Roscoff Harbor (Table S2). Total nitrogen contents however, are very similar. At sediment depth greater than $3.5 \mathrm{~cm}$, no significant difference between the two sites was noticeable.

Reduced Sulfur Species - At the time when the worms were collected for NGS sequencing (October 2013), the two locations greatly differed by the amount of sulfide in the upper layer of the sediment (Fig. 2A). At the water-sediment interface, the concentrations of solid reduced sulfur species increased in sediments of Roscoff Harbor but not at Le Laber. At one $\mathrm{cm}$ depth, concentrations of reduced sulfur species were 5-6 times higher at the Roscoff Harbor than at Le Laber site. Below the depth of $3 \mathrm{~cm}$, concentrations of AVS (the less stable fraction of solid reduced sulfur to oxidation) and CRS (the less reactive fraction of solid 
reduced sulfur) ranged from 141 to $978 \mathrm{mgS} \mathrm{kg}^{-1}$ and from 447 and $712 \mathrm{mgS} \mathrm{kg}^{-1}$ for the Roscoff Harbor and Le Laber sites, respectively.

349 A survey of dissolved sulfide concentrations performed two years later (from July to 350 December 2015) monitored with DGT-AgI probes showed that these species were more 351 abundant in a deeper part of the cores (i.e. below 4-5 cm depth). Interestingly, sulfide 352 concentrations were on average higher at the Roscoff Harbor (from 8.2 to $11.60 \mathrm{mg} \mathrm{L}^{-1}$ ) than at Le Laber (from 0.58 to $5.52 \mathrm{mg} \mathrm{L}^{-1}$ ) (Fig. S2), in a way similar to the AVS and CRS

354 concentrations. More precisely, in the first $3 \mathrm{~cm}$, where the worms live, the inter-site 355 differences were even more marked, with levels ranging between 1.08 and $5.75 \mathrm{mg} \mathrm{L}^{-1}$ for 356 the Roscoff Harbor as opposed to 0 and $0.27 \mathrm{mg} \mathrm{L}^{-1}$ for Le Laber (Fig. S2 and Table 2). Trace metals - Total metal concentrations $(\mathrm{Cd}, \mathrm{Co}, \mathrm{Cr}, \mathrm{Cu}, \mathrm{Mn}, \mathrm{Ni}, \mathrm{Pb}$ and $\mathrm{Zn}$ ) in the 358 sediments clearly indicate that the Roscoff Harbor was enriched in metals when compared 359 to Le Laber site (Table 1 and S2), especially in $\mathrm{Cu}$ for which the ratio reaches 6.1 (Roscoff 360 Harbor/Le Laber). Following the normalization of values, it is worth noting that all the EF 361 values in the sediments of Le Laber site were lower than or equal to 1, excepted for $\mathrm{Pb}(\mathrm{EF}$ $362=1.4$ ). These findings clearly suggest that sediments from Le Laber can be used as an 363 unmodified environment regarding metal concentrations. Conversely, the EF values for Cd, $364 \mathrm{Cu}, \mathrm{Zn}$ and $\mathrm{Pb}$ were much higher (3.5, 2.8, 2 and 1.6) in the Roscoff Harbor, suggesting a low 365 to moderate anthropic contamination of sediments.

366 The toxicity index (TI) was calculated for each sample (averaged over the first $5 \mathrm{~cm}$ of 367 sediment) from July to December 2015 (Fig. S3). During this period, all TI values were 368 below zero, indicating that no significant toxicity has been encountered in sediments (i.e. 369 most of trace metals are efficiently trapped by sulfides forming AVS). The bioavailability of 370 metals should therefore be extremely limited as sulfides are in excess. The TI values are 
371 however consistently greater in the Roscoff Harbor throughout the sampling period 372 because of higher Zn concentrations.

\subsection{Micro-organisms associated with Capitella differ between localities and} associated habitats

Morphological observations - In October 2013 (RNAseq sampling date), around 20\% of worms exhibited an epibiosis with long white hair-like projection at the Roscoff Harbor (Figs. 2B, 3B, D). This association was also observed in some Capitella worms from Le Laber during the 2015 temporal survey of the two localities, notably during the summer period. Electron microscopy and FISH hybridizations using the probe EUB338 evidenced dense assemblages of filamentous structures (Figs 3D, 4A), with small bacteria attached to larger and more visible ones strongly anchored in the tegument (Figs. 3B, 4B, C) of the epibiotic Capitella worms only (Fig. 4, Figs. 3F, G). The larger epibiotic microorganisms were easily observable under transmission or light microscopy (Fig. 3A-D) displaying a size reaching 50 microns from basal to apical ends with refringent cytoplasmic inclusions resembling sulfur granules typical of sulfur-oxidizing bacteria, the lack of a nucleus based on DAPI staining (Fig. 4) and the presence of a large vacuole in the center of the cells (Figs 4D, E). Large Capitella epibionts also displayed a larger basal bacterium with an elongated rod shape, atop of which a second, spherical-to-elongate bacterium is budding.

A few worms were also parasitized by nematodes (Trophomera sp.) living in the coelomic cavity of the worm (Figs.S4D, E), by vorticellid ciliates attached to the tegument (Figs. S4A, B, C) or by gut gregarines (Ancora saggitata) (Figs. S4F, G).

Abundance of symbionts lineages based on RNAseq data - The most abundant assembled sequences regroup three different Capitella rRNAs as expected (BoidinWichlacz et al., Under review). These sequences were not considered in the following analyses. The other recovered contigs corresponded to organisms associated to Capitella, 
which could be either epibionts (tegument), part of the gut contents, or parasites. In the

following analyses, we only considered contigs with abundances greater than 100 FPKM in at least one of the libraries. Some of these may correspond to different fragments of the same organism (e.g. fragment of 28S, another fragment of 28S, fragment of 18S, etc.).

400 The sequence assembly followed by quantification allowed us to identify contigs 401 corresponding to associated organisms that are found in all three groups (1/ non epibiotic 402 Capitella from Le Laber 2/ non epibiotic Capitella from the Roscoff Harbor and 3/ epibiotic 403 Capitella from the Roscoff Harbor) but in variable abundances (Table 3), contigs that are 404 more common at Le Laber (Table 4), and contigs that are more abundant in the group 405 corresponding to animals with epibiotic microorganisms (Table 5). Capitella from the three 406 compared groups are host to a variety of eukaryotes at intermediate occurrence (Tables 3407 5).

408 Among the organisms found in all three groups in variable proportions, there is a total of 40951 contigs (Table 3). The great majority of these organisms are eukaryotes (86.3\%), in 410 particular apicomplexan fish parasites (31.8\%) for which Capitella could be an 411 intermediary host (e.g. Eimeria leucisci, Sphaerospora dicentrarchi, Kudoa iwatai, 412 Sarcocystis $\mathrm{sp})$. The contig that ranks second in Table 3 corresponds to the known parasitic 413 gut gregarine Ancora sagittata (Apicomplexa, Ancoridae) (Simdyanov et al., 2017) 414 specifically associated to Capitella (Fig. 4). Other abundant types of organisms are ciliates 415 (e.g. Vorticella sp.), nematodes, and annelids that could be part of the gut contents 416 (Paramphinome jeffreysi, Tubificoides brownie; Fig. 3). Bacteria occupy lower ranks in this 417 list (ranks 28, 31, 34, 35, 44, 49, and 51), which could reflect their lesser abundance and 418 also the fact they are single-celled (as opposed to most eukaryotes mentioned earlier). The 41915 top-ranking contigs are usually more abundant in the epibiotic animals from the Roscoff 420 Harbor, with the exception of ranks 1 (a polychaete, possibly from the gut contents), 6 and 
42111 (a nematode) that are more abundant in the animals from the control site. The animals

422 from the Roscoff Harbor that do not exhibit an epibiosis tend to have low or very low

423 abundances of these contigs.

424 The animals from Le Laber site exhibited a series of taxa corresponding to the contigs that

425 are found in very low abundances in the Roscoff Harbor (Table 4). Six of these eight contigs

426 correspond to apicomplexan parasites, the two remaining ones correspond to a bivalve

427 (likely found in the gut contents), and Corynebacterium.

428 The contigs that are found in much greater abundance in epibiotic animals (Table 5)

429 differed greatly from the organisms identified in Tables 3 and 4 . The Capitella specimens

430 from the two other groups (non-epibiotic from the Roscoff Harbor and le Laber) have very

431 low abundances of these contigs (FPKM $\leq 20) .31$ out of the 38 contigs $(81.6 \%)$ correspond

432 to bacteria, mostly within the Gammaproteobacteria. Eight of these bacterial contigs (21\%)

433 correspond to sulfur-oxidizing bacteria (Thiomargarita, the most abundant, and

434 Thioalkalivibrio). Six of the bacterial contigs (15.8\%) correspond to mollicutes, a group

435 usually found in the guts of invertebrates.

436 3.3. Phylogenetic affiliation of the large bacterial epibiont to the genus 437 Thiomargarita

438 A near full length 16S rRNA-encoding sequence (6 reads) affiliated with Thiomargarita was 439 identified in clone libraries from the two specimens displaying the large epibiont (Table 440 S5). The same sequence was successfully amplified from isolated large epibionts using 441 Thiomargarita-specific primers, supporting that this sequence actually corresponds to the 442 large epibiont morphotype.

443 Analysis performed on the near full-length Thiomargarita sequences indicate a single 16S 444 rRNA phylotype that shared $98 \%$ of sequence identity and clustered in a $100 \%$ bootstrap445 supported clade with sequences of Candidatus 'Thiomargarita nelsonii' recovered from the 
446 Costa Rica margin and the Namibian upwelling zone. This clade is distinct from that 447 containing Candidatus 'T. namibiensis' (Salman et al., 2011) (Fig. 5). The sequence was 448 registered in GenBank (accession number MZ053470).

3.4. Prevalence of the epibiosis with Thiomargarita according to the season, and the size and gender of Capitella' worms

452 Observed prevalence of Thiomargarita fluctuated between zero and 0.44 among sampling 453 dates (average over the year: 0.10 ), with 95\% of observations between zero and 0.31 and 454 a median prevalence of 0.08 . Worm size as estimated from the width at the fifth setiger varied between 0.19 and $1.56 \mathrm{~mm}$ (average: $0.54 \mathrm{~mm}$ ) with a slightly fluctuating average value (between 0.43 and $0.68 \mathrm{~mm}$ ), without any clear temporal trend. The numbers of males, females and undetermined individuals also do not vary much between sampling dates (Fig. S7). A statistical analysis of time-series was performed using the association occurrences as a quantitative variable and the sampling date, size and gender of the worm as explanatory variables. Overall, the probability of association with Thiomargarita

461 increases in summer and increases with the worm's size (Fig. 6). Independently of worm's 462 size, this probability is also higher for males and undetermined individuals than for females

463 (Figs. S5 and S6). As many models have comparable AICc and Akaike values (Table S6), 464 model predictions have been explored using the Akaike-weighted average of all tested 465 models (Figs. 6, S5 and S6). The analysis of evidence ratios (ratio of Akaike weights of 466 models incorporating or not the focal variable) of all explanatory variables (Table S7) 467 indicates that all variables have likely effects, except 'site' (implausible effect), and 468 'sex:date', 'sex:date' ${ }^{2 \prime}$ and 'sex:size:date ${ }^{2 \prime}$ interactions (only plausible effects) using the 469 vocabulary of (Massol et al., 2007). 


\section{genotypes}

473 As we know that Capitella spp. from the Roscoff Harbor and Laber represent a complex of

474 three cryptic species (Boidin-Wichlacz et al., Under review), series of individuals with and

475 without epibionts from Le Laber and the Roscoff Harbor were barcoded using the 476 mitochondrial Cox-1 gene to test whether the epibiotic phenotype was species-specific. The 477 obtained phylogenetic tree (Fig. 7) confirmed the co-occurrence of the three different 478 mitochondrial lineages (C-Channel1, C-Channel2 and C-Atlantic) in our set of epibiotic and 479 non-epibiotic worms. The two most closely related species (C-Channel1 and C-Atlantic: see 480 (Boidin-Wichlacz et al., Under review)) dominate the assemblage and correspond to about $48190 \%$ of the sampling. The epibiosis with the Thiomargarita-like epsilon proteobacteria was 482 checked and is present in all of the mitochondrial lineages examined, including the rarer C483 Channel2 one.

\subsection{Sulfide tolerance of non-epibiotic versus epibiotic Capitella spp.}

A tolerance assay was performed on adult worms from the Roscoff Harbor presenting the epibiotic and non-epibiotic phenotypes, exposed to 0,1 and $3 \mathrm{mM}$ of sulfides. As shown in

figure 8 , both phenotypes survive to a $3 \mathrm{mM}$ exposure for 1 day (23h30). After this delay, non-epibiotic worms (NE) start immediately to die reaching a 50\% mortality after $48 \mathrm{~h}$. On the contrary, epibiotic worms (E) first die after an additional 36h delay (first death 491 observed at $58 \mathrm{~h} 30$ ) and reached the $50 \%$ mortality following a $88 \mathrm{~h}$ post exposure to $3 \mathrm{mM}$. 492 In both cases, $\mathrm{NE}$ and $\mathrm{E}$ all die following a post exposure to $3 \mathrm{mM}$ of $88 \mathrm{~h}$ and $91 \mathrm{~h}$, 493 respectively while non-exposed individuals $(0 \mathrm{mM})$ remain alive until the end of the 494 experiment (104h). A dose-dependent effect was observable, with a shift of the $1 \mathrm{mM}$ 495 mortality curve in NE when compared to the $3 \mathrm{mM}$ curve showing a better survival of this 
later group to a $1 \mathrm{mM}$ than to a $3 \mathrm{mM}$ exposure. No mortality was observed in E exposed to $1 \mathrm{mM}$ during the allotted time.

\section{DISCUSSION}

The appearance of animals exhibiting an epibiosis is concomitant with a higher level of sulfides

Capitella worms from the English Channel, which also represent three distinct

503 mitochondrial lineages (Boidin-Wichlacz et al., Under review) are opportunistic species 504 that occupy the top $5 \mathrm{~cm}$ of sediment of estuaries and polluted harbors: a black zone 505 (named thiobiome) rich in organic matter especially in the muddy sediments. The surveyed 506 sites are enriched in silts, with a high concentration of organic carbon in the Roscoff Harbor.

507 Concentrations, availability and lability of metals estimated through SEM were greater in 508 the Roscoff Harbor than in the Laber site (excepted for $\mathrm{Cr}$ ) without reaching levels of 509 contamination as high as those reported in industrialized harbor of the Northern France 510 (e.g. Boulogne Harbor (Table S4)(Cuvillier-Hot et al., 2018) (Fig. S2)). Although 511 concentrations of ETM slightly varied during the monitoring period, the sediments from 512 both sites never reached the threshold of the toxicity index (calculated at a macroscopic 513 scale from about $1 \mathrm{~g}$ of sediments) classically used to investigate polluted environments. 514 By contrast, the two sites colonized by the worms strongly exhibited spatial and/or temporal differences in AVS concentrations reaching highly toxic levels for most organisms

516 including other Capitella species from different locations (higher than $10 \mathrm{mM}$ ) (Dubilier, 517 1988). This could be explained by differences in the hydrologic conditions and the 518 anthropogenic contamination between the two sites over the year. The seasonal survey 519 shows that sulfide production takes place throughout the year in the Roscoff Harbor while 520 it mostly occurs in the summer period at Le Laber. In the Harbor sediments, the important 
521 input of organic matter linked to anthropogenic activities and anthropization processes 522 results in the production of high quantities of AVS through the bioreduction of sulfates by 523 the Sulfate-Reducing Bacteria (SRB) (https://doi.org/10.1016/i.scitotenv.2018.08.278 ;

524 https://doi.org/10.1016/S0967-0637(02)00092-4). The confinement of the Roscoff

525 Harbor added to the accumulation of cadavers of crabs due to fishing offloading activities 526 in this zone, promotes green algal proliferation and a high retention of organic matter (with 527 enrichments in TOC and nitrogen contents), and, as a consequence, a greater production of 528 sulfide due to microbial degradation over the year when compared with Le Laber. By 529 contrast, although not affected by off falls, the site of the Laber is subjected to a short and 530 local eutrophication due a river input that favors intense proliferation of benthic algae at 531 the surface of the sediment in this area during the summer period. By being open to the 532 ocean, tidal currents renew twice a day the oxygenation of the water sediment interface of 533 the Le Laber site, promoting the quick reoxidation of AVS 534 (https://doi.org/10.1016/j.oceano.2018.03.003 ; doi 10.1007/s10498-005-4574-2). 535 These differential sediment compositions qualitatively and quantitatively are likely to 536 change the community structure of micro- and macroorganisms co-inhabiting with 537 Capitella. Concomitantly with these geochemistry differences over the year and space, we 538 observed two distinct phenotypes of Capitella worms from the English Channel, which are 539 co-occurring independently between at least three genetic lineages of the worm: one 540 characterized by a tegument covered by a consortium of large filamentous bacteria and 541 another one with an epidermis perfectly clean of any microorganisms as checked by 542 electron microscopy and confirmed by PCR and RNASeq. Epibiosis with the large 543 filamentous bacteria were only observed in sediments where the sulfide concentrations 544 reach levels known to be toxic for other Capitella species (Cuomo, 1985). Under these 545 conditions, the prevalence of the epibiotic association is around $20-30 \%$ and mostly affects 
546 larger individuals. Trace metals do not seem to affect the epibiosis, since during our survey 547 over the year 2015, the appearance of animals exhibiting an epibiosis increased 548 concomitantly with the level of sulfides in the site Le Laber.

\section{Distinct prokaryotic and eukaryotic associations with the host phenotypes}

551 We assessed the diversity of microorganisms associated with the worm using a RNAseq 552 approach on animals with and without epibionts in the two distinct nearby habitats. First 553 assignments of contig sequences shown that these small worms are associated with a wide 554 variety of prokaryotes and eukaryotes. The composition of the associated communities 555 clearly varies according to the environmental setting. All animals used for the RNAseq 556 study were collected at the same time of the year. Although in the three groups (i.e. Le Laber 557 worms without epibionts, Roscoff Harbor worms with and without epibionts), the 558 apicomplexan fish parasites are very common, bacterial associates and vorticellid ciliates 559 were quite distinct. We did not observe any lethal effects of ciliates on Capitella maintained 560 in the laboratory (unpublished data) by contrast to the enhanced mortality reported for

561 freshwater leeches covered by vorticellid ciliates (Gouda, 2006).

562 Even though Capitella with and without epibionts were found in the same sediment sample 563 at the Roscoff Harbor, associated bacterial communities from epibiotic animals were quite 564 distinct from non-epibiotic Capitella. Assuming the animals were exposed to the same 565 environmental conditions in the Roscoff Harbor, this observation suggests that the two 566 groups are characterized either by physiological or genetic differences. As previously 567 shown, the barcoding effort revealed that up to three lineages are present in Roscoff, all of 568 which can be the host to the large epibiotic filamentous bacteria. As a consequence, 569 intraspecific genetic differences do not explain the presence of epibiosis and the 570 polymorphic physiological response of the worms seems to represent the best explanation. 
571 Pollution, even at sub-lethal levels can affect the physiology of organisms and affect their

572 relationships with other organisms. Several studies have shown that, when they are not

573 directly lethal, thermal and/or chemical modifications of the environment often induce

574 endocrine and behavioral changes in marine organisms, as well as alterations of their

575 energetic metabolism and immunity (Harvell et al., 1999; Waldichuk, 1979). Cuvillier-Hot

576 et al. (2018) showed that heavy metals and phthalates, even at concentrations below the

577 toxicity index, alter the immune response as well as the trans-generational immune

578 priming of natural populations of the coastal annelid Hediste diversicolor and make them

579 less resistant to an experimental infection by the environmental bacterium Bacillus

580 hwajinpoensis SW-72 isolated from the burrow of the worm (Bernier et al., 2019; Cuvillier-

581 Hot et al., 2018). These observations clearly show the impact of changing environmental

582 conditions on host-bacteria interactions in marine invertebrates.

583

584 Worm epibiosis is characterized by a tegumental association with the giant sulfur

585 oxidizing bacterium Thiomargarita sp.

586 The combined analyses of the RNAseq data, the targeted bacterial 16S amplification results

587 and microscopic observations, allowed the estimation of the abundance and the phylotype

588 diversity of the epibiotic bacteria associated with the Capitella worms in the Roscoff

589 Harbor. Most abundant bacteria fall into three groups: (i) sulfur-oxidizing bacteria (mostly

590 Thiomargarita but also Thiotrix, Thioalkalivibrio, and Sulfuromonas), (ii) mollicutes

591 (including Spiroplasma), typically found in invertebrate guts, and (iii) spirochaetes. We

592 identified the largest and most visible epibiont as being a large gammaproteobacterium

593 belonging to genus Thiomargarita, closely related to Candidatus 'Thiomargarita nelsonii'.

594 This is the first report of Thiomargarita in a coastal ecosystem. This giant

595 chemolithotrophic bacterium was often encountered as a free-living species associated 
with deep-sea microbial mats. Thiomargarita were also found attached to the byssus of a mussel at deep-sea hydrothermal vents (Schulz, 2006), the shell of gastropod Provanna laevis at deep-sea methane cold seeps, and on the integument of other seep fauna (Bailey et al., 2011). The ecological behavior of the gastropod Provanna laevis was shown to be modified by the presence of Thiomargarita, the snail orienting its shell downward to allow 601 its Thiomargarita epibionts to be exposed to sulfide-rich water while the animal had access 602 to the oxygen-rich overlaying water, leaving its head partially exposed (Bailey et al., 2011). 603 The fluctuating sulfide-driven chemosynthetic environment appears as an obvious shared 604 characteristic between the Capitella and the seep fauna habitats.

605 Unlike its close relatives Thioploca and Beggiatoa, Thiomargarita are not motile. They store 606 elemental sulfur as granules at the periphery of a very large vacuole that occupies $98 \%$ of 607 the cell volume where nitrate is stored (Schulz, 2006). Because of their lack of motility, 608 Thiomargarita cells must live in an environment where they will be alternatively exposed 609 to sulfide in the porewater and to nitrate in the overlaying seawater. Compared to 610 previously reported Thiomargarita morphologies, the cells attached to Capitella are more 611 elongated but the observation of budding structures are similar to those reported in 612 Provanna laevis and byssal threads of Bathymodiolus mussels from deep-sea cold seeps 613 (Bailey et al., 2011), and suggests that the cells are actively growing. Unlike Thioploca, 614 whose populations decline at oxygen concentrations greater than $3 \mu \mathrm{M}$, and Beggiatoa 615 mats, which thrive with oxygen concentration of 1-2.5 $\mu \mathrm{M}$, Thiomargarita cells can 616 withstand exposure to full atmospheric oxygen concentrations (Schulz, 2006). 617 Thiomargarita morphotypes have also been observed attached to various debris while 618 sorting the sediment samples, suggesting their ability to efficiently colonize a wide variety 619 of surfaces, including Capitella. The presence of Thiomargarita can easily be viewed as a 620 form of biofouling. Their density was, however, higher on the worms, suggesting that these 
621 animals offer a more suitable environment. Moreover, we found that Thiomargarita was 622 present on the tegument of the three genetic lineages, cryptic species of Capitella, but at a

623 higher prevalence on large worms during the summer period, irrespectively of gender, 624 although more frequently encountered on males and indeterminate individuals.

625

Is thiobiont epibiosis a facultative mutualistic association to face transient concentrations of sulfide?

628 The complex of Capitella species living in the English Channel is exposed to high concentrations of sulfide in the sediment while pumping overlaying oxygenated water by peristalsis in their burrow. Since Thiomargarita is a non-motile, facultative anaerobic sulfur-oxidizing bacterium, the association with the animal could thus represent an 632 opportunistic strategy from the bacterial viewpoint, bridging the oxic-anoxic gap and 633 allowing bacteria access to both electron donors and acceptors. On the other hand, sulfide 634 uptake might be a way to detoxify the environment of Capitella and a positive by-product 635 of the bacterium's activity, although this hypothesis needs to be tested. Other sulfur 636 bacteria detected could interact as a consortium of smaller filamentous bacteria working 637 at the surface of Thiomargarita cells, as already shown in Namibia sediments (Bailey et al., 638 2011) but also found in association with the hydrothermal-vent species Alvinella 639 pompejana (Le Bris and Gaill, 2006). During the survey of epibiosis over nearly a year, we 640 found a greater abundance of worms with Thiomargarita in during the summer on the 641 largest animals from both sampled sites. Summer is the period of the year when 642 temperatures are the highest and thus during which bacterial degradation of organic 643 matter, producing sulfide, is likely to be at its highest in the sediment. The prevalence of 644 the association depends on the presence of free bacteria in the mud what remains to be 645 seasonally surveyed. One might assume that Thiomargarita which oxidizes dissolved 
646 sulfide in the pore water grow better during the summer period (Schulz, 2006).

647 Capitella is a typical member of the 'sulfide system'. Fenchel \& Riedl (Fenchel and Riedl, 648 1970) coined this term to describe life under these hostile conditions (later called 649 'thiobiome' or 'thiobios' by Boaden (Boaden, 1975)). Although the thiobiome allows less 650 competitive stress, specific physical and structural adaptations are needed for the survival 651 and thriving of this complex and specific biome. Our observations suggest that at highly 652 "toxic" levels of hydrogen sulfide, physiological adaptations of Capitella alone could not be 653 sufficient to detoxify the reduced sulfur compounds and that a facultative epidermal 654 association with Thiomargarita and other sulfur oxidizing bacteria available in sediment 655 may constitute a vital additional strategy. The tolerance assay provided here evidenced that 656 the observed epibiosis is beneficial to the host when subjected to highly sulfide-rich 657 environments. Besides detoxication, sulfur-oxidizing epibionts may provide nutrients to 658 the host as suggested for deep sea hydrothermal annelids (Desbruyères et al., 1983). 659 Capitella has been shown to feed on free-living autotrophs that use sulfide oxidation to fix $660 \mathrm{CO}_{2}$ (Hiroaki et al., 2001). Thiobionts might supply Capitella in nutrients presumably 661 explaining why epibiotic specimens are larger than the non-epibiotic ones.

662 There is ample empirical evidence of symbioses providing protection against specific 663 natural enemies, e.g. in aphids facing parasitoids and predators (Dion et al., 2011; Oliver et 664 al., 2014; Polin et al., 2014) or pathogens (Clay, 2014; Tasiemski et al., 2015). Such 665 symbioses have also been suggested as potential means to explain the success of some 666 invasive species in new habitats (Amsellem et al., 2017; Chabrerie et al., 2019; Macke et al., 667 2017). While many of the aforementioned symbioses involved obligatory endosymbionts, 668 the present data bring to light an adaptive advantage of a facultative ectosymbiosis to face 669 changing habitats.

670 A derived question was to know if this Capitella-Thiomargarita association was species- 
671 specific; to find a specific niche may allow to avoid competition with congeneric species.

672 Capitella teleta and C. capitata which form a cryptic species complex (Grassle and Grassle,

673 1976; Nygren, 2014). Even if the populations of Capitella inhabiting Roscoff constitute an

674 assemblage of cryptic species (Boidin-Wichlacz et al. under review), barcode analyses

675 performed on the main lineages showed that the epibiotic association is not completely 676 genetically determined (e.g. an intraspecific polymorphism of the immune genes involved

677 in the control of the association might exist). The facultative association is likely due to 678 physiological differences between individuals, more or less correlated to their size and 679 possibly micro-environments at the scale of the worm itself. The observation could also 680 mean that Thiomargarita and other epibiotic bacteria correspond to biofouling/parasitic 681 agents capable of colonizing a range of invertebrates, including Capitella from different 682 species, when they are under high sulfidic stresses.

\section{Conclusion}

684 Our data provide clear evidences of the impact of sediment microgeochemistry on 685 associations between Capitella and its surrounding microorganisms with the peculiar 686 development of a transient beneficial epibiosis in worms exposed to high sulfide concentrations. Occurrence and maintenance of an epibiotic community depend on the 688 host's ability to control the epibiont's colonization and proliferation through its immune 689 actors. Such defense is probably influenced by variable environmental conditions. 690 Consequently, the next step will be to investigate how and if the immune system of Capitella 691 can become permissive to the establishment of this facultative epibiosis as observed for the 692 hydrothermal vent worm, Alvinella pompejana and shrimp Rimicaris exoculata (Le Bloa et 693 al., 2020; Tasiemski et al., 2014). Regardless of future findings, this emphasizes the 694 importance of investigating symbiotic associations in their proper environmental context. 
This project was funded by the CNRS INEE APEGE PolCa (2012) programme, by the FRB-

698 Nord Pas de Calais VERMER program (2013-2016), the BQR emergent Université de Lille (2013), the Total Foundation PIONEER project (2015-2018). MCR benefitted from a Brazil-

France Sandwich fellowship for her fieldwork in Roscoff. The Soil Analyses Laboratory

(INRA, Arras) is warmly acknowledged for the analysis of the total organic carbon and

nitrogen in the sediments. ICP-AES measurements were performed on the Chevreul

Institute Platform (U-Lille / CNRS). The Region Hauts de France and the French government are warmly acknowledged for the co-funding of this apparatus.

\section{References}

Altschul SF, Madden TL, Schäffer AA, Zhang J, Zhang Z, Miller W, et al. Gapped BLAST and PSI-BLAST: a new generation of protein database search programs. Nucleic Acids Research 1997; 25: 3389-3402.

Amsellem L, Brouat C, Duron O, Porter SS, Vilcinskas A, Facon B. Chapter Three Importance of Microorganisms to Macroorganisms Invasions: Is the Essential Invisible to the Eye? (The Little Prince, A. de Saint-Exupéry, 1943). In: Bohan DA, Dumbrell AJ, Massol F, editors. Advances in Ecological Research. 57. Academic Press, 2017, pp. 99-146.

Andersen PK, Gill RD. cox's regression model for counting processes: a large sample study. 1982.

Ankley GT, Benoit DA, Hoke RA, Leonard EN, West CW, Phipps GL, et al. Development and evaluation of test methods for benthic invertebrates and sediments: Effects of flow rate and feeding on water quality and exposure conditions. Archives of Environmental Contamination and Toxicology 1993; 25: 12-19.

Audry S, Schäfer J, Blanc G, Jouanneau J-M. Fifty-year sedimentary record of heavy metal pollution $(\mathrm{Cd}, \mathrm{Zn}, \mathrm{Cu}, \mathrm{Pb})$ in the Lot River reservoirs (France). Environmental Pollution 2004; 132: 413-426.

Bailey JV, Salman V, Rouse GW, Schulz-Vogt HN, Levin LA, Orphan VJ. Dimorphism in methane seep-dwelling ecotypes of the largest known bacteria. The Isme Journal 2011; 5: 1926.

Bellec L, Bonavita M-AC, Hourdez S, Jebbar M, Tasiemski A, Durand L, et al. Chemosynthetic ectosymbionts associated with a shallow-water marine nematode. Scientific Reports 2019; 9: 7019.

Bernier C, Boidin-Wichlacz C, Tasiemski A, Hautekeete N, Massol F, Cuvillier-Hot V. Transgenerational Immune Priming in the Field: Maternal Environmental Experience Leads to Differential Immune Transfer to Oocytes in the Marine Annelid Hediste diversicolor. Genes (Basel) 2019; 10. 
Blake JA, Grassle JP, Eckelbarger KJ. Capitella teleta, a new species designation for the opportunistic and experimental Capitella sp. I, with a review of the literature for confirmed records. 2009 2009; 2: 29.

Boaden PJS. Anaerobiosis, Meiofauna and Early Metazoan Evolution. Zoologica Scripta 1975; 4: 21-24.

Boidin-Wichlacz C, Jollivet D, Papot C, Roisin L, Massol F, Tasiemski A. Genetic diversification and life-cycle of the polychaete Capitella spp. from the English Channel: Evidence for sympatric cryptic species and alternative reproductive strategies. Under review.

Bright M, Lallier FH. The biology of Vestimentiferan tubeworms. Oceanography and Marine Biology: An Annual Review, Volume 48. CRC Press, 2010, pp. 213-265.

Brooks AW, Kohl KD, Brucker RM, van Opstal EJ, Bordenstein SR. Phylosymbiosis: Relationships and Functional Effects of Microbial Communities across Host Evolutionary History. PLoS biology. 15, 2017, pp. e1002587.

Bulgheresi S. All the microbiology nematodes can teach us. FEMS Microbiology Ecology 2016; 92.

Burnham KP, Anderson DR, Huyvaert KP. AIC model selection and multimodel inference in behavioral ecology: some background, observations, and comparisons. Behavioral Ecology and Sociobiology 2011; 65: 23-35.

Carrier TJ, Reitzel AM. The Hologenome Across Environments and the Implications of a Host-Associated Microbial Repertoire. Frontiers in Microbiology 2017; 8.

Cavanaugh CM. Symbiotic chemoautotrophic bacteria in marine invertebrates from sulphide-rich habitats. Nature 1983; 302: 58-61.

Cavanaugh CM, Gardiner SL, Jones ML, Jannasch HW, Waterbury JB. Prokaryotic cells in the hydrothermal vent tube worm Riftia pachyptila Jones: Possible chemoautotrophic symbionts. Science 1981; 213: 340-342.

Chabrerie 0, Massol F, Facon B, Thevenoux R, Hess M, Ulmer R, et al. Biological Invasion Theories: Merging Perspectives from Population, Community and Ecosystem Scales. Wiley, 2019.

Clay K. Editorial: Defensive symbiosis: a microbial perspective. Functional Ecology 2014; 28: 293-298.

Cuomo MC. Sulphide as a larval settlement cue forCapitella sp I. Biogeochemistry 1985; 1 : 169-181.

Cuvillier-Hot V, Gaudron SM, Massol F, Boidin-Wichlacz C, Pennel T, Lesven L, et al. Immune failure reveals vulnerability of populations exposed to pollution in the bioindicator species Hediste diversicolor. Science of The Total Environment 2018; 613-614: 1527-1542.

Davide V, Pardos M, Diserens J, Ugazio G, Thomas R, Dominik J. Characterisation of bed sediments and suspension of the river Po (Italy) during normal and high flow conditions. Water Research 2003; 37: 2847-2864.

Desbruyères D, Gaill F, Laubier L, Prieur D, Rau GH. Unusual nutrition of the "Pompeii worm" Alvinella pompejana (polychaetous annelid) from a hydrothermal vent environment: SEM, TEM, 13C and 15N evidence. Marine Biology 1983; 75: 201-205.

Dion E, Zélé F, Simon J-C, Outreman Y. Rapid evolution of parasitoids when faced with the symbiont-mediated resistance of their hosts. Journal of Evolutionary Biology 2011; 24: 741-750.

Dubilier N. H2S-A settlement cue or a toxic substance for Capitella sp. I larvae? The Biological Bulletin 1988; 174: 30-38. 
Dubilier N, Bergin C, Lott C. Symbiotic diversity in marine animals: the art of harnessing chemosynthesis. Nat Rev Microbiol 2008; 6: 725-40.

Dubilier N, Blazejak A, Rühland C. Symbioses between Bacteria and Gutless Marine Oligochaetes. In: Overmann J, editor. Molecular Basis of Symbiosis. Springer Berlin Heidelberg, Berlin, Heidelberg, 2006, pp. 251-275.

Duperron S. Characterization of Bacterial Symbionts in Deep-Sea Fauna: Protocols for Sample Conditioning, Fluorescence In Situ Hybridization, and Image Analysis. In: McGenity TJ, Timmis KN, Nogales B, editors. Hydrocarbon and Lipid Microbiology Protocols: Field Studies. Springer Berlin Heidelberg, Berlin, Heidelberg, 2017, pp. 343-362.

Duperron S, Halary S, Lorion J, Sibuet M, Gaill F. Unexpected co-occurrence of six bacterial symbionts in the gills of the cold seep mussel Idas sp. (Bivalvia: Mytilidae). Environmental Microbiology 2008; 10: 433-445.

Duperron S, Nadalig T, Caprais J-C, Sibuet M, Fiala-Médioni A, Amann R, et al. Dual Symbiosis in a Bathymodiolus sp. Mussel from a Methane Seep on the Gabon Continental Margin (Southeast Atlantic): 16S rRNA Phylogeny and Distribution of the Symbionts in Gills. Applied and Environmental Microbiology 2005; 71: 1694.

Felbeck H. Chemoautotrophic Potential of the Hydrothermal Vent Tube Worm, Riftia pachyptila Jones (Vestimentifera). Science 1981; 213: 336-8.

Fenchel TM, Riedl RJ. The sulfide system: a new biotic community underneath the oxidized layer of marine sand bottoms. Marine Biology 1970; 7: 255-268.

Ferrari J, Vavre F. Bacterial symbionts in insects or the story of communities affecting communities. Philos Trans R Soc Lond B Biol Sci 2011; 366: 1389-400.

Gamenick I, Vismann B, Grieshaber MK, Giere O. Ecophysiological differentiation of Capitella capitata (Polychaeta). Sibling species from different sulfidic habitats. Marine Ecology Progress Series 1998; 175: 155-166.

Gao Y, Lesven L, Gillan D, Sabbe K, Billon G, De Galan S, et al. Geochemical behavior of trace elements in sub-tidal marine sediments of the Belgian coast. Marine Chemistry 2009; 117: 88-96.

Gasnier-Fauchet F, Gharib A, Nardon P. Comparison of methionine metabolism in symbiotic and aposymbiotic larvae of Sitophilus oryzae L. (Coleoptera: Curculionidae)-I. Evidence for a glycine N-methyltransferase-like activity in the aposymbiotic larvae. Comparative Biochemistry and Physiology Part B: Comparative Biochemistry 1986; 85: 245-250.

Gilbert SF, Bosch TCG, Ledon-Rettig C. Eco-Evo-Devo: developmental symbiosis and developmental plasticity as evolutionary agents. Nature Reviews Genetics 2015; 16 : 611-622.

Gouda HA. The effect of peritrich ciliates on some freshwater leeches from Assiut, Egypt. Journal of Invertebrate Pathology 2006; 93: 143-149.

Grassle J, Grassle J. Sibling species in the marine pollution indicator Capitella (polychaeta). Science 1976; 192: 567-569.

Harvell CD, Kim K, Burkholder JM, Colwell RR, Epstein PR, Grimes DJ, et al. Emerging marine diseases--climate links and anthropogenic factors. Science 1999; 285: 1505-10.

Hiroaki T, Sam W, Shigeru M, Megumi S, Sagiri I, Kazuhiro K. Exploitation of a chemosynthetic food resource by the polychaete Capitella sp. I. Marine Ecology Progress Series 2001; 216: 119-127.

Huang X, Madan A. CAP3: A DNA Sequence Assembly Program. Genome Research 1999; 9: 868-877. 
Jackson CH. flexsurv: A Platform for Parametric Survival Modeling in R. J Stat Softw 2016; 70.

Kaltenpoth M, Engl T. Defensive microbial symbionts in Hymenoptera. Functional Ecology 2014; 28: 315-327.

Kitamori R. Benthos as an environmental indicator (S) with special reference to indicator species. In: Problems CotJESoE, editor. Aquatic environment. 2. Kankyo to seibutsu shihyo, Kyoritsu Shuppan, Tokyo, p., 1975, pp. 265-273.

Kohl KD, Weiss RB, Cox J, Dale C, Dearing MD. Gut microbes of mammalian herbivores facilitate intake of plant toxins. Ecology Letters 2014; 17: 1238-1246.

Kumar S, Stecher G, Tamura K. MEGA7: Molecular Evolutionary Genetics Analysis Version 7.0 for Bigger Datasets. Molecular Biology and Evolution 2016; 33: 1870-1874.

Larkin MA, Blackshields G, Brown NP, Chenna R, McGettigan PA, McWilliam H, et al. Clustal W and Clustal X version 2.0. Bioinformatics 2007; 23: 2947-2948.

Le Bloa S, Boidin-Wichlacz C, Cueff-Gauchard V, Rosa RD, Cuvillier-Hot V, Durand L, et al. Antimicrobial Peptides and Ectosymbiotic Relationships: Involvement of a Novel Type IIa Crustin in the Life Cycle of a Deep-Sea Vent Shrimp. Front Immunol 2020; 11: 1511.

Le Bris N, Gaill F. How does the annelid Alvinella pompejana deal with an extreme hydrothermal environment? Reviews in Environmental Science and Bio/Technology 2006; 6: 197.

Lee B-G, Lee J-S, Luoma SN, Choi HJ, Koh C-H. Influence of Acid Volatile Sulfide and Metal Concentrations on Metal Bioavailability to Marine Invertebrates in Contaminated Sediments. Environmental Science \& Technology 2000; 34: 4517-4523.

Li B, Dewey CN. RSEM: accurate transcript quantification from RNA-Seq data with or without a reference genome. BMC Bioinformatics 2011; 12: 323.

Lourino-Cabana B, Billon G, Lesven L, Sabbe K, Gillan DC, Gao Y, et al. Monthly variation of trace metals in North Sea sediments. From experimental data to modeling calculations. Marine Pollution Bulletin 2014; 87: 237-246.

Macke E, Tasiemski A, Massol F, Callens M, Decaestecker E. Life history and ecoevolutionary dynamics in light of the gut microbiota. Oikos 2017; 126: 508-531.

Margulis L. Symbiogenesis and symbionticism. In: L. Margulis RFE, editor. Symbiosis as a source of evolutionary innovation: speciation and morphogenesis MIT press, Cambridge, 1991, pp. pp 1-14.

Massol F, David P, Gerdeaux D, Jarne P. The influence of trophic status and large-scale climatic change on the structure of fish communities in Perialpine lakes. The Journal of animal ecology 2007; 76: 538-551.

McFall-Ngai M. Are biologists in 'future shock'? Symbiosis integrates biology across domains. Nat Rev Microbiol 2008; 6: 789-92.

McFall-Ngai M, Hadfield MG, Bosch TC, Carey HV, Domazet-Loso T, Douglas AE, et al. Animals in a bacterial world, a new imperative for the life sciences. Proc Natl Acad Sci U S A 2013; 110: 3229-36.

Moran NA, Wernegreen JJ. Lifestyle evolution in symbiotic bacteria: insights from genomics. Trends in Ecology \& Evolution 2000; 15: 321-326.

Morsy MR, Oswald J, He J, Tang Y, Roossinck MJ. Teasing apart a three-way symbiosis: Transcriptome analyses of Curvularia protuberata in response to viral infection and heat stress. Biochemical and Biophysical Research Communications 2010; 401: 225230. 
Nougué 0, Gallet R, Chevin L-M, Lenormand T. Niche limits of symbiotic gut microbiota constrain the salinity tolerance of Brine shrimp. The American Naturalist 2015; 186: 390-403.

Nygren A. Cryptic polychaete diversity: a review. Zoologica Scripta 2014; 43: 172-183.

Oliver KM, Smith AH, Russell JA. Defensive symbiosis in the real world - advancing ecological studies of heritable, protective bacteria in aphids and beyond. Functional Ecology 2014; 28: 341-355.

Pardo EV, Teixeira LLS, Amaral ACZ. Morphometric analysis of Capitella capitata (Polychaeta, Capitellidae). Iheringia. Série Zoologia 2010; 100: 13-18.

Pearson TH, Rosenberg R. Macrobenthic succession in relation to organic enrichment and pollution of the environment. Oceanogr. mar. Biol. A. Rev. 1978: 229-311.

Petersen JM, Zielinski FU, Pape T, Seifert R, Moraru C, Amann R, et al. Hydrogen is an energy source for hydrothermal vent symbioses. Nature 2011; 476: 176-180.

Polin S, Simon J-C, Outreman Y. An ecological cost associated with protective symbionts of aphids. Ecology and Evolution 2014; 4: 836-840.

Polz MF, Felbeck H, Novak R, Nebelsick M, Ott JA. Chemoautotrophic, sulfur-oxidizing symbiotic bacteria on marine nematodes: Morphological and biochemical characterization. Microbial Ecology 1992; 24: 313-329.

Reish DJ. Bristle worms (Annelida: Polychaeta). In: Hart CW, Fuller, S. L. H, editor. Pollution ecology of estuarine invertebrates. Academic Press, New York,, 1979, pp. 78-125.

Richier S, Furla P, Plantivaux A, Merle P-L, Allemand D. Symbiosis-induced adaptation to oxidative stress. Journal of Experimental Biology 2005; 208: 277.

Salman V, Amann R, Girnth A-C, Polerecky L, Bailey JV, Høgslund S, et al. A single-cell sequencing approach to the classification of large, vacuolated sulfur bacteria. Systematic and Applied Microbiology 2011; 34: 243-259.

Schmieder R, Edwards R. Quality control and preprocessing of metagenomic datasets. Bioinformatics 2011; 27: 863-864.

Schmieder R, Lim YW, Edwards R. Identification and removal of ribosomal RNA sequences from metatranscriptomes. Bioinformatics 2011; 28: 433-435.

Schulz HN. The Genus Thiomargarita. In: Dworkin M, Falkow S, Rosenberg E, Schleifer K-H, Stackebrandt E, editors. The Prokaryotes: Volume 6: Proteobacteria: Gamma Subclass. Springer New York, New York, NY, 2006, pp. 1156-1163.

Simdyanov TG, Guillou L, Diakin AY, Mikhailov KV, Schrével J, Aleoshin VV. A new view on the morphology and phylogeny of eugregarines suggested by the evidence from the gregarine Ancora sagittata (Leuckart, 1860) Labbé, 1899 (Apicomplexa: Eugregarinida). PeerJ 2017; 5: e3354.

Sterckeman T, Douay F, Baize D, Fourrier H, Proix N, Schvartz C, et al. Trace element distributions in soils developed in loess deposits from northern France. European Journal of Soil Science 2006; 57: 392-410.

Stewart FJ, Cavanaugh CM. Symbiosis of Thioautotrophic Bacteria with Riftia pachyptila. In: Overmann J, editor. Molecular Basis of Symbiosis. Springer Berlin Heidelberg, Berlin, Heidelberg, 2006, pp. 197-225.

Stewart FJ, Newton ILG, Cavanaugh CM. Chemosynthetic endosymbioses: adaptations to oxic-anoxic interfaces. Trends in Microbiology 2005; 13: 439-448.

Tasiemski A, Jung S, Boidin-Wichlacz C, Jollivet D, Cuvillier-Hot V, Pradillon F, et al. Characterization and function of the first antibiotic isolated from a vent organism: the extremophile metazoan Alvinella pompejana. PLoS One 2014; 9: e95737.

Tasiemski A, Massol F, Cuvillier-Hot V, Boidin-Wichlacz C, Roger E, Rodet F, et al. Reciprocal immune benefit based on complementary production of antibiotics by the leech 
Hirudo verbana and its gut symbiont Aeromonas veronii. Scientific Reports 2015; 5: 17498.

Teasdale PR, Hayward S, Davison W. In situ, High-Resolution Measurement of Dissolved Sulfide Using Diffusive Gradients in Thin Films with Computer-Imaging Densitometry. Analytical Chemistry 1999; 71: 2186-2191.

Tsutsumi H, Wainright S, Montani S, Saga M, Ichihara S, Kogure K. Exploitation of a chemosynthetic food resource by the polychaete Capitella sp. I. Marine Ecology Progress Series 2001; 216: 119-127.

Wada M, Wu SS, Tsutsumi H, Kita-Tsukamoto K, Hyung-Ki D, Nomura H, et al. Effects of sodium sulfide on burrowing activity of Capitella sp. I and bacterial respiratory activity in seawater soft-agar microcosms. Plankton and Benthos Research 2006; 1: 117-122.

Waldichuk M. The assessment of sublethal effects of pollutants in the sea. Review of the problems. Philos Trans R Soc Lond B Biol Sci 1979; 286: 399-424.

Walkley A, Black C. Centre d'expertise en analyse environnementale du Québec et Ministère de l'agriculture, des pêcheries et de l'alimentation du Québec. Détermination de la matière organique par dosage du carbone organique dans les sols agricoles: méthode Walkley-Black modifiée, MA 2003.

Wood A. Sulphur cycling on the continents: Wetlands, terrestrial ecosystems and associated water bodies (Scope 48): edited by R.W. Howarth, J.W.B. Stewart and M.V. Ivanov, John Wiley, 1992. $€ 75.00$ hbk (xx + 350 pages) ISBN 047193153 5. Trends in Ecology \& Evolution 1992; 7: 356. 
952 Figure 1: Location of the study (Roscoff, France) with the sampling sites. Sites coordinates 953 are the following: Le Laber: $48^{\circ} 42^{\prime} 47.67^{\prime \prime} \mathrm{N} 4^{\circ} 0^{\prime} 5.17^{\prime \prime} 0-48^{\circ} 42^{\prime} 45.92^{\prime \prime} \mathrm{N} 4^{\circ} 0^{\prime} 3.85^{\prime \prime} 0-$ $95448^{\circ} 42^{\prime} 45.12^{\prime \prime} \mathrm{N} 4^{\circ} 0^{\prime} 3.60^{\prime \prime} \mathrm{O}$, Roscoff Harbor: 48²3'35.46"N 358'52.05"O -48²43'34.49"N 955



Figure 2: (A) Sedimentary AVS and CRS concentration profiles (mgS kg-1 sed) in Roscoff 957 Harbor (blue line) and Le Laber (red line) performed in November 2014 (corresponding to 958 the sampling of the animals for NGS sequencing). (B) Semi-thin sections of Capitella 959 sampled for the NGS sequencing: not colonized (in Le Laber, FPKM1 and in the Roscoff 960 Harbor, FPKM2) and colonized by the epibiotic community (in the Roscoff Harbor only, 961 FPKM3).

962 Figure-3: Visible (top) and electron microscopy (bottom) showing non epibiotic (A, C) and 963 epibiotic Capitella (B, D). Squares show a zoom on the microbial epibiotic community.

964 Figure 4: Epibionts of Capitella spp. (A) Electron microscopy of the Thiomargarita like 965 bacteria (C) Notice that Thiomargarita-like bacteria are strongly anchored on the tegument 966 and (A, B) themselves host epibiotic communities most likely consisting of bacteria some 967 displaying filamentous morphologies. (D) Several Thiomargarita-like structures and other 968 microbial morphotypes. (E) DAPI staining of a Thiomargarita-like structure (in the center) 969 attached to the tegument of Capitella. (F, G) FISH hybridization on the tegument of an 970 epibiotic Capitella specimen using the generalist probe EUB338. Notice the abundance and 971 diversity of bacterial morphologies including rods, cocci and filamentous bacteria.

972 Figure 5: Phylogenetic reconstruction of the position of the Thiomargarita sp. sequence 973 obtained from 16rRNA clone libraries obtained from epibiont-covered Capitella annelids. 974 See material and methods for detail (FYI: Maximum likelihood using a General Time 975 Reversible Model using MEGA7. Heterogeneity in rates of evolution was accounted by using 
976 Gamma distributed rates (5 categories and invariants). 1140 nucleotide positions were 977 analyzed. Scale bar corresponds to $2 \%$ sequence variation. Bootstrap values at nodes were 978 obtained based on 100 ML replications ( $>50$ shown).

979 Figure 6: Predicted probability of association with epibiotic microorganisms as a function 980 of the time of the year (month, x-axis) and the size of the worm (in mm, y-axis), obtained 981 from model-averaging 166 GLMs linking site, size, date, date ${ }^{2}$ and sex to association with 982 epibiotic microorganisms. Predictions are made for a uniform sampling of worms among 983 the sexes (undetermined, females and males represent 1/3 of the sample each), the sizes 984 (uniform distribution between 0 and $1.8 \mathrm{~mm}$ ), the sampling dates and the sampling sites. 985 The color of each square on the heatmap indicates the average predicted probability of 986 association of all worms of that size sampled at that date, following the legend on the right. 987 Figure 7: Neighbor-joining tree reconstruction of epibiotic and non-epibiotic Capitella spp. 988 individuals barcoded using the mitochondrial marker Cox-1. Distances between individuals 989 were calculated according to the substitution model HKY.

990 Figure 8: Tolerance tests to sulfides. Kaplan-Meier plots showing the survivorship of non991 epibiotic (red) versus epibiotic (blue) worms sampled from the Roscoff Harbor (2020) 992 experimentally exposed to 0 (solid lines), $1 \mathrm{mM}$ (dotted lines) and $3 \mathrm{mM}$ (dashed lines) 993 concentrations of sodium sulfides. Time in hours. 
Table 1: Total and $\mathrm{HCl} 1 \mathrm{M}$-extracted metals concentrations in the first $5 \mathrm{~cm}$ depth sediments of Le Laber and the Roscoff harbor (fraction $<63 \mu \mathrm{m}$ ). For $\mathrm{HCl} 1 \mathrm{M}$ extraction, an average has been calculated from results obtained between July and December 2015. See table S3 for discrete values and table S4 for a comparison with sediments from other similar North Atlantic French stations (Boulogne, Gravelines and Authie).

\begin{tabular}{|c|c|c|c|c|c|c|c|c|c|c|c|c|c|}
\hline & & \multicolumn{8}{|c|}{ Concentration (mg kg-1) } & \multicolumn{4}{|c|}{ Concentration $\left(\mathrm{g} \mathrm{kg}^{-1}\right)$} \\
\hline & & $\mathrm{Cd}$ & Co & $\mathrm{Cr}$ & $\mathrm{Cu}$ & $\mathrm{Mn}$ & $\mathrm{Ni}$ & $\mathrm{Pb}$ & $\mathrm{Zn}$ & $\mathrm{Ca}$ & $\mathrm{Fe}$ & $\mathrm{Mg}$ & $\mathrm{Al}$ \\
\hline \multirow[t]{3}{*}{ Laber } & Total & 0.1 & 6.5 & 51 & 6.0 & 165 & 6.9 & 19.4 & 42 & 14 & 10.2 & 4.3 & 38.5 \\
\hline & $\mathrm{HCl} 1 \mathrm{M}$ & 0.1 & ND & 2.2 & 1.6 & 15 & 0.9 & 4.1 & 11.1 & 5.6 & 2.1 & 0.8 & - \\
\hline & Lability (\%) & 76.0 & - & 4.3 & 17.9 & 9.0 & 13.7 & 21.3 & 26.6 & 39.2 & 20.9 & 18.7 & - \\
\hline Roscoff & Total & 0.4 & 10.1 & 54 & 37.6 & 264 & 13.3 & 30 & 111 & 69 & 21.2 & 10.7 & 51.2 \\
\hline \multirow[t]{2}{*}{ Harbor } & $\mathrm{HCl} 1 \mathrm{M}$ & 0.1 & 0.0 & 4.8 & 6.7 & 32 & 1.6 & 8.6 & 27.8 & 15 & 3.8 & 0.9 & - \\
\hline & Lability (\%) & 15.1 & 0.1 & 8.7 & 17.9 & 12.1 & 11.7 & 28.7 & 25.1 & 21.2 & 18.1 & 8.5 & - \\
\hline \multicolumn{2}{|c|}{$\begin{array}{l}\text { Ratio of total :Roscoff } \\
\text { Harbor/Laber }\end{array}$} & 4 & 1.55 & 1.06 & 6.27 & 1.60 & 1.93 & 1.55 & 2.64 & 4.93 & 2.08 & 2.49 & 1.33 \\
\hline
\end{tabular}

ND: Not detected 
Table 2: Dissolved sulfide concentrations ( $\mathrm{mg} \mathrm{L}^{-1}$ ). Averaged values for 0-3, 3-15 and 0-15 cm sedimentary horizons from Le Laber and Roscoff Harbor sites (in 2015). In bold, the concentration values where the worms live.

\begin{tabular}{|c|c|c|c|c|c|c|c|c|c|}
\hline & & \multicolumn{8}{|c|}{ Concentration (mg/L) } \\
\hline & & $\overline{11 / 8}$ & $12 / 8$ & $18 / 8$ & $21 / 8$ & $1 / 9$ & $9 / 9$ & $15 / 9$ & $24 / 9$ \\
\hline \multirow{3}{*}{ Le Laber } & $0-3 \mathrm{~cm}$ & & 0.15 & 0.01 & & $<0.005$ & - & $<0.005$ & 0.27 \\
\hline & $3-15 \mathrm{~cm}$ & & 0.68 & 3.1 & & 3.1 & & 5.9 & 6.8 \\
\hline & $0-15 \mathrm{~cm}$ & & 0.58 & 2.5 & & 2.5 & & 4.8 & 5.5 \\
\hline \multirow{3}{*}{$\begin{array}{l}\text { Roscoff } \\
\text { Harbor }\end{array}$} & $0-3 \mathrm{~cm}$ & 5.8 & & & 1.1 & & 2.8 & & \\
\hline & $3-15 \mathrm{~cm}$ & 13 & & & 10 & & 12 & & \\
\hline & $0-15 \mathrm{~cm}$ & 12 & & & 8.2 & & 9.8 & & \\
\hline
\end{tabular}


Table 3: Contigs with intermediate FPKM values (ratios between 30 and 0.03). Le Laber sample (FPKM1), Roscoff Harbor sample without (FPKM2) or with (FPKM3) epibiotic microorganisms. Only hits for FPKM values greater than 100 are represented. Contigs ranked in decreasing order of the greatest FPKM value (shaded in grey).

\begin{tabular}{|c|c|c|c|c|c|c|}
\hline $\begin{array}{l}\text { Accession } \\
\text { number }\end{array}$ & E-value & Genbank description & Biology & FPKM1 & FPKM2 & FPKM3 \\
\hline AY838865.1 & 0 & Paramphinome jeffreysi 28S ribosomal RNA gene, partial sequence & Polychaete & 2702 & 658 & 243 \\
\hline KX982503.1 & 0 & $\begin{array}{l}\text { Ancora sagittata isolate Ancora } 2011 \text { external transcribed spacer, } \\
\text { partial sequence; } 18 \mathrm{~S} \text { rRNA gene, ITS } 1,5.8 \mathrm{~S} \text { rRNA gene, ITS } 2 \text {, and } \\
28 \mathrm{~S} \text { rRNA gene, complete sequence; and external transcribed } \\
\text { spacer, partial sequence }\end{array}$ & $\begin{array}{l}\text { Gregarine of } \\
\text { Capitella }\end{array}$ & 925 & 48 & 1594 \\
\hline DQ779991.1 & $610^{-88}$ & $\begin{array}{l}\text { Gymnodinium aureolum strain GrAr01 } 18 \mathrm{~S} \text { ribosomal RNA gene, } \\
\text { partial sequence; ITS 1, 5.8S ribosomal RNA gene, ITS 2, and large } \\
\text { subunit ribosomal RNA gene, complete sequence; external } \\
\text { transcribed spacer, partial sequence }\end{array}$ & $\begin{array}{l}\text { Dinoflagellate } \\
\text { algae }\end{array}$ & 1042 & 19 & 1550 \\
\hline EF100367.1 & $10^{-114}$ & $\begin{array}{l}\text { Uncultured eukaryote clone D5P10A10 18S ribosomal RNA gene, } \\
\text { partial sequence }\end{array}$ & Apicomplexan? & 509 & 33 & 1134 \\
\hline EF100398.1 & 0 & $\begin{array}{l}\text { Uncultured eukaryote clone D2P03E11 18S ribosomal RNA gene, } \\
\text { partial sequence }\end{array}$ & $?$ & 875 & 31 & 1086 \\
\hline GU479649.1 & 0 & $\begin{array}{l}\text { Eimeria leucisci isolate BLI637-\#637 18S ribosomal RNA gene, } \\
\text { partial sequence }\end{array}$ & $\begin{array}{l}\text { Coccidian } \\
\text { apicomplexa fish } \\
\text { parasite }\end{array}$ & 936 & 43 & 106 \\
\hline AY179976.1 & $910^{-177}$ & $\begin{array}{l}\text { Uncultured eukaryote clone CCI31 18S small subunit ribosomal } \\
\text { RNA gene, partial sequence }\end{array}$ & Apicomplexan? & 530 & 258 & 869 \\
\hline KC558064.1 & $510^{-89}$ & $\begin{array}{l}\text { Uncultured fungus clone NTS_28S_047E_2_f6 28S ribosomal RNA } \\
\text { gene, partial sequence }\end{array}$ & $?$ & 121 & 0 & 863 \\
\hline JX178933.1 & 0 & $\begin{array}{l}\text { Vorticella sp. } 4 \text { JG-2011 clone } 3318 \mathrm{~S} \text { ribosomal RNA gene, partial } \\
\text { sequence; ITS 1, 5.8S ribosomal RNA gene, and ITS } 2 \text {, complete } \\
\text { sequence; } 28 \mathrm{~S} \text { ribosomal RNA gene, partial sequence }\end{array}$ & Peritrich ciliate & 150 & 170 & 840 \\
\hline GU927604.1 & $410^{-94}$ & $\begin{array}{l}\text { Uncultured eukaryote clone F5K2Q4C04IDZ7B 28S ribosomal RNA } \\
\text { gene, partial sequence }\end{array}$ & Ciliate & 166 & 16 & 636 \\
\hline EF990727.1 & $510^{-88}$ & $\begin{array}{l}\text { Rhabditoides inermiformis strain SB328 28S large subunit } \\
\text { ribosomal RNA gene, partial sequence }\end{array}$ & $\begin{array}{l}\text { Free-living } \\
\text { nematodes }\end{array}$ & 634 & 25 & 542 \\
\hline
\end{tabular}




\begin{tabular}{|c|c|c|c|c|c|c|}
\hline AY256244.1 & $210^{-119}$ & $\begin{array}{l}\text { Uncultured eukaryote isolate E6 small subunit ribosomal RNA } \\
\text { gene, partial sequence }\end{array}$ & $?$ & 369 & 152 & 586 \\
\hline GU927618.1 & $410^{-94}$ & $\begin{array}{l}\text { Uncultured eukaryote clone F5K2Q4C04IVOMC 28S ribosomal RNA } \\
\text { gene, partial sequence }\end{array}$ & $?$ & 88 & 0 & 578 \\
\hline AY835682.2 & 0 & $\begin{array}{l}\text { Uncultured peritrich clone IAFDv27 } 18 \mathrm{~S} \text { ribosomal RNA gene, } \\
\text { partial sequence }\end{array}$ & Peritrich ciliate & 125 & 23 & 555 \\
\hline GU927271.1 & $410^{-25}$ & $\begin{array}{l}\text { Uncultured eukaryote clone F5K2Q4C04H81PH 28S ribosomal } \\
\text { RNA gene, partial sequence }\end{array}$ & $?$ & 252 & 56 & 430 \\
\hline AB189984.1 & $710^{-83}$ & $\begin{array}{l}\text { Contracaecum spiculigerum gene for } 28 \mathrm{~S} \text { ribosomal RNA, partial } \\
\text { sequence }\end{array}$ & Bird parasite & 46 & 446 & 128 \\
\hline KF147653.1 & 0 & $\begin{array}{l}\text { Nematoda environmental sample clone NEMAK34 18S ribosomal } \\
\text { RNA gene, partial sequence }\end{array}$ & $?$ & 156 & 7 & 414 \\
\hline KF601317.1 & $410^{-54}$ & $\begin{array}{l}\text { Sarcocystis arctica isolate Vl2.2 28S ribosomal RNA gene, partial } \\
\text { sequence }\end{array}$ & $\begin{array}{l}\text { Vertebrate } \\
\text { parasite }\end{array}$ & 201 & 0 & 398 \\
\hline KC869522.1 & $910^{-88}$ & $\begin{array}{l}\text { Isodictya grandis voucher NCI43928S ribosomal RNA gene, partial } \\
\text { sequence }\end{array}$ & Marine sponge & 380 & 74 & 394 \\
\hline FJ969135.1 & 0 & $\begin{array}{l}\text { Plectus tenuis strain ChGaSp5 small subunit ribosomal RNA gene, } \\
\text { partial sequence }\end{array}$ & $\begin{array}{l}\text { Free-living } \\
\text { nematodes }\end{array}$ & 17 & 22 & 371 \\
\hline EF100367.1 & $310^{-105}$ & $\begin{array}{l}\text { Uncultured eukaryote clone D5P10A10 18S ribosomal RNA gene, } \\
\text { partial sequence }\end{array}$ & $?$ & 366 & 153 & 60 \\
\hline AB611781.1 & $310^{-64}$ & $\begin{array}{l}\text { Fukuia kurodai ooyagii gene for 28S ribosomal RNA, partial } \\
\text { sequence, specimen_voucher: personal:Kameda Y.:5609 }\end{array}$ & Gastropod & 343 & 0 & 240 \\
\hline EF100367.1 & $310^{-125}$ & $\begin{array}{l}\text { Uncultured eukaryote clone D5P10A10 18S ribosomal RNA gene, } \\
\text { partial sequence }\end{array}$ & Apicomplexan? & 173 & 0 & 323 \\
\hline FJ417074.1 & 0 & $\begin{array}{l}\text { Sphaerospora dicentrarchi isolate M0749 28S large subunit } \\
\text { ribosomal RNA gene, partial sequence }\end{array}$ & Fish parasite & 320 & 3 & 65 \\
\hline KF147653.1 & 0 & $\begin{array}{l}\text { Nematoda environmental sample clone NEMAK34 18S ribosomal } \\
\text { RNA gene, partial sequence }\end{array}$ & $?$ & 11 & 38 & 319 \\
\hline FJ417074.1 & $10^{-140}$ & $\begin{array}{l}\text { Sphaerospora dicentrarchi isolate M0749 28S large subunit } \\
\text { ribosomal RNA gene, partial sequence }\end{array}$ & Fish parasite & 306 & 0 & 69 \\
\hline JX391808.1 & 0 & $\begin{array}{l}\text { Uncultured bacterium clone NS093 } 16 \mathrm{~S} \text { ribosomal RNA gene, } \\
\text { partial sequence }\end{array}$ & $?$ & 302 & 0 & 23 \\
\hline HG315671.1 & 0 & Formosa agariphila KMM 3901, complete genome & $\begin{array}{l}\text { Algal bacterial } \\
\text { associate }\end{array}$ & 287 & 1 & 19 \\
\hline
\end{tabular}




\begin{tabular}{|c|c|c|c|c|c|c|}
\hline FJ417074.1 & 0 & $\begin{array}{l}\text { Sphaerospora sp. M0379 28S large subunit ribosomal RNA gene, } \\
\text { partial sequence }\end{array}$ & Fish parasite & 285 & 8 & 76 \\
\hline AY641571.1 & 0 & $\begin{array}{l}\text { Kudoa iwatai isolate J small subunit ribosomal RNA gene, partial } \\
\text { sequence }\end{array}$ & Fish parasite & 276 & 6 & 102 \\
\hline FQ032815.1 & $410^{-131}$ & $\begin{array}{l}\text { Uncultured Sphingobacteria bacterium, whole genome shotgun } \\
\text { sequence }\end{array}$ & $?$ & 265 & 0 & 11 \\
\hline JQ723993.1 & $510^{-180}$ & $\begin{array}{l}\text { Vorticellides sp. } 2 \text { MD-2012 small subunit ribosomal RNA gene, } \\
\text { partial sequence; macronuclear }\end{array}$ & Peritrich ciliate & 58 & 29 & 257 \\
\hline AY179976.1 & $310^{-177}$ & $\begin{array}{l}\text { Uncultured eukaryote clone CCI31 } 18 \mathrm{~S} \text { small subunit ribosomal } \\
\text { RNA gene, partial sequence }\end{array}$ & $?$ & 246 & 67 & 76 \\
\hline HM031979.1 & 0 & Cytophaga sp. UDC385 16S ribosomal RNA gene, partial sequence & $\begin{array}{l}\text { Free-living } \\
\text { bacterium }\end{array}$ & 244 & 2 & 15 \\
\hline JX391440.1 & $510^{-150}$ & $\begin{array}{l}\text { Uncultured bacterium clone N0004 16S ribosomal RNA gene, } \\
\text { partial sequence }\end{array}$ & $?$ & 233 & 0 & 18 \\
\hline EF067920.1 & $510^{-98}$ & Phaeodactylum tricornutum chloroplast, complete genome & Diatom & 222 & 0 & 117 \\
\hline DQ377695.1 & 0 & $\begin{array}{l}\text { Sphaerospora sp. IF-2006 from Mugil curema small subunit } \\
\text { ribosomal RNA gene, partial sequence }\end{array}$ & Fish parasite & 218 & 0 & 75 \\
\hline EF100398.1 & 0 & $\begin{array}{l}\text { Uncultured eukaryote clone D2P03E11 18S ribosomal RNA gene, } \\
\text { partial sequence }\end{array}$ & $?$ & 191 & 15 & 155 \\
\hline FJ417074.1 & $810^{-178}$ & $\begin{array}{l}\text { Sphaerospora dicentrarchi isolate M0749 28S large subunit } \\
\text { ribosomal RNA gene, partial sequence }\end{array}$ & Fish parasite & 170 & 0 & 81 \\
\hline GU928472.1 & $610^{-68}$ & $\begin{array}{l}\text { Uncultured eukaryote clone F5K2Q4C04H5ZBN 28S ribosomal } \\
\text { RNA gene, partial sequence }\end{array}$ & ? & 33 & 0 & 169 \\
\hline AF185190.1 & $210-133$ & Eurythoe sp. AMW4444 28S ribosomal RNA gene, partial sequence & Polychaete & 154 & 36 & 117 \\
\hline FN563149.1 & 0 & Rhodococcus equi $103 \mathrm{~S}$ chromosome & $\begin{array}{l}\text { Pathogen causing } \\
\text { pneumonia in } \\
\text { horses } \\
\end{array}$ & 148 & 1 & 7 \\
\hline AB636470.1 & $10^{-98}$ & Kudoa ogawai gene for $18 \mathrm{~S}$ ribosomal RNA, partial sequence & Fish parasite & 142 & 0 & 81 \\
\hline FJ557946.1 & 0 & $\begin{array}{l}\text { Uncultured bacterium clone ET_G_4f03 } 16 \mathrm{~S} \text { ribosomal RNA gene, } \\
\text { partial sequence }\end{array}$ & $?$ & 135 & 0 & 6 \\
\hline FJ417058.1 & $10^{-69}$ & $\begin{array}{l}\text { Kudoa dianae isolate M0290 28S large subunit ribosomal RNA gene, } \\
\text { partial sequence }\end{array}$ & Fish parasite & 133 & 0 & 77 \\
\hline
\end{tabular}




\begin{tabular}{|c|c|c|c|c|c|c|}
\hline GU479649.1 & 0 & $\begin{array}{l}\text { Tubificoides brownae isolate CE3387 18S ribosomal RNA gene, } \\
\text { partial sequence; ITS 1, 5.8S ribosomal RNA gene, and ITS 2, } \\
\text { complete sequence; } 28 \mathrm{~S} \text { ribosomal RNA gene, partial sequence }\end{array}$ & $\begin{array}{l}\text { Free-living } \\
\text { oligochaete }\end{array}$ & 131 & 0 & 13 \\
\hline FJ417074.1 & $410^{-103}$ & $\begin{array}{l}\text { Sphaerospora dicentrarchi isolate M0749 28S large subunit } \\
\text { ribosomal RNA gene, partial sequence }\end{array}$ & Fish parasite & 128 & 18 & 37 \\
\hline JX178767.1 & $210^{-108}$ & $\begin{array}{l}\text { Zoothamnium sp. } 1 \text { JG-2011 } 18 \mathrm{~S} \text { ribosomal RNA gene, partial } \\
\text { sequence }\end{array}$ & Peritrich ciliate & 95 & 49 & 120 \\
\hline СР004404.1 & $710^{-169}$ & Psychromonas sp. CNPT3, complete genome & $\begin{array}{l}\text { Facultative } \\
\text { anaerobic free- } \\
\text { living }\end{array}$ & 21 & 0 & 113 \\
\hline JQ743689.1 & $610^{-134}$ & $\begin{array}{l}\text { Uncultured peritrich ciliate clone GDH_F10 18S ribosomal RNA } \\
\text { gene, partial sequence }\end{array}$ & Peritrich ciliate & 46 & 113 & 33 \\
\hline KF077586.1 & 0 & $\begin{array}{l}\text { Uncultured bacterium clone nck } 74 \mathrm{~g} 02 \mathrm{c} 116 \mathrm{~S} \text { ribosomal RNA gene, } \\
\text { partial sequence }\end{array}$ & & 103 & 0 & 3 \\
\hline
\end{tabular}


Table 4: Contigs found with greater FPKM values in Le Laber sample (FPKM1) compared to the Roscoff harbor without (FPKM2) or with (FPKM3) epibiotic microorganisms' samples. Only hits for FPKM values greater than 100 are represented. Contigs ranked according to decreasing values of FPKM1.

\begin{tabular}{|c|c|c|c|c|c|c|}
\hline $\begin{array}{l}\text { Accession } \\
\text { number }\end{array}$ & E-value & Genbank description & Biology & FPKM1 & FPKM2 & FPKM3 \\
\hline KC816721.1 & $810^{-113}$ & $\begin{array}{l}\text { Apicomplexa sp. type N clone N66 clone } 218 \mathrm{~S} \text { ribosomal RNA } \\
\text { gene, partial sequence }\end{array}$ & Coral parasite & 675 & 0 & 0 \\
\hline JX044549.1 & $710^{-77}$ & $\begin{array}{l}\text { Toxoplasma gondii strain CASTELLS chromosome Ia region } 5 \\
\text { genomic sequence }\end{array}$ & Animal parasite & 651 & 95 & 1 \\
\hline JN256118.1 & $610^{-72}$ & $\begin{array}{l}\text { Sarcocystis sp. ex Corvus monedula isolate kuos1 28S ribosomal } \\
\text { RNA gene, partial sequence }\end{array}$ & Bird parasite & 582 & 0 & 1 \\
\hline FJ417076.1 & $410^{-114}$ & $\begin{array}{l}\text { Sphaerospora sp. M0379 28S large subunit ribosomal RNA gene, } \\
\text { partial sequence }\end{array}$ & Fish parasite & 478 & 79 & 2 \\
\hline X75453.1 & $710^{-99}$ & $\begin{array}{l}\text { Toxoplasma gondii (strain P) rDNA for } 17 \mathrm{~s}, 5.8 \mathrm{~s}, 26 \mathrm{~s} \text {, and } 5 \mathrm{~s} \\
\text { ribosomal RNA }\end{array}$ & Animal parasite & 468 & 5 & 0 \\
\hline СР001601.1 & 0 & Corynebacterium aurimucosum ATCC 700975, complete genome & $\begin{array}{l}\text { Mycolic acid- } \\
\text { containing } \\
\text { actinomycetes }\end{array}$ & 436 & 0 & 2 \\
\hline HQ243019.1 & $310^{-35}$ & $\begin{array}{l}\text { Uncultured Glomus clone ZHwq2-227 18S rRNA gene, partial } \\
\text { sequence; ITS } 1,5.8 \mathrm{~S} \text { rRNA gene, and ITS } 2 \text {, complete sequence; } \\
\text { and } 28 \mathrm{~S} \text { rRNA gene, partial sequence }\end{array}$ & Bivalve & 355 & 0 & 0 \\
\hline AF109679.1 & $510^{-58}$ & $\begin{array}{l}\text { Sarcocystis mucosa small subunit ribosomal RNA gene, partial } \\
\text { sequence }\end{array}$ & $\begin{array}{l}\text { Mammal } \\
\text { parasite }\end{array}$ & 211 & 16 & 0 \\
\hline
\end{tabular}


Table 5: Contigs found with FPKM values at 50 times greater in animals with (FPKM3) and without (FPKM2) epibiotic organisms compared with animals from Le Laber (FPKM1). Only hits for FPKM values greater than 100 are represented. Contigs ranked according to decreasing values of FPKM3.

\begin{tabular}{|c|c|c|c|c|c|c|}
\hline $\begin{array}{l}\text { Accession } \\
\text { number }\end{array}$ & E-value & Genbank description & Biology & FPKM1 & FPKM2 & FPKM3 \\
\hline HF954103.1 & 0 & $\begin{array}{l}\text { Uncultured Thiomargarita sp. partial 16S rRNA gene, } \\
\text { clone NAM094 }\end{array}$ & Giant sulfur bacterium & 2 & 0 & 2708 \\
\hline JX198551.1 & 0 & $\begin{array}{l}\text { Uncultured bacterium clone Tui57 } 16 \mathrm{~S} \text { ribosomal } \\
\text { RNA gene, partial sequence }\end{array}$ & $\begin{array}{l}\text { Oceanospirillales symbiotic } \\
\text { with vent snail Alviniconcha }\end{array}$ & 19 & 0 & 2477 \\
\hline JQ768460.1 & $710-130$ & $\begin{array}{l}\text { Spiroplasma sp. crk } 16 \mathrm{~S} \text { ribosomal RNA gene, partial } \\
\text { sequence; } 16 \mathrm{~S}-23 \mathrm{~S} \text { ribosomal RNA intergenic spacer, } \\
23 \mathrm{~S} \text { ribosomal RNA gene, and } 23 \mathrm{~S}-5 \mathrm{~S} \text { ribosomal RNA } \\
\text { intergenic spacer, complete sequence; and } 5 \mathrm{~S} \\
\text { ribosomal RNA gene, partial sequence }\end{array}$ & Field cricket gut mollicute & 5 & 0 & 1897 \\
\hline NR_121985.1 & 0 & $\begin{array}{l}\text { Candidatus Hepatoplasma crinochetorum } \\
\text { ribosomal RNA, complete sequence }\end{array}$ & $\begin{array}{l}\text { Isopod midgut gland } \\
\text { mollicute bacterium }\end{array}$ & 4 & 7 & 1625 \\
\hline NR_076721.1 & 0 & $\begin{array}{l}\text { Thioalkalivibrio sp. K90mix strain } \text { K90mix } 23 \mathrm{~S} \\
\text { ribosomal RNA, complete sequence }\end{array}$ & $\begin{array}{l}\text { Haloalkaliphilic } \\
\text { oxidizing bacterium }\end{array}$ & 9 & 1 & 1359 \\
\hline FR774200.1 & 0 & $\begin{array}{l}\text { Thiomargarita sp. NAM092 partial 23S rRNA gene and } \\
\text { ITS1, clone NAM092 }\end{array}$ & Giant sulfur bacterium & 3 & 0 & 1257 \\
\hline FJ654610.1 & 0 & $\begin{array}{l}\text { Uncultured gamma proteobacterium rone } \\
\text { 005_D02_06-017371_low_week_1 16S ribosomal RNA } \\
\text { gene, partial sequence }\end{array}$ & Cnidarian-associated & 20 & 0 & 1239 \\
\hline JN935865.1 & $510^{-66}$ & $\begin{array}{l}\text { Mycoplasma pulmonis strain Ash (PG34) 16S } \\
\text { ribosomal RNA gene, partial sequence; 16S-23S } \\
\text { ribosomal RNA intergenic spacer, complete sequence; } \\
\text { and 23S ribosomal RNA gene, partial sequence }\end{array}$ & Animal parasite & 0 & 0 & 1219 \\
\hline FR690959.1 & $310^{-121}$ & $\begin{array}{l}\text { Candidatus Thiomargarita nelsonii partial 16S rRNA } \\
\text { gene and ITS1, isolate NAM071 }\end{array}$ & Giant sulfur bacterium & 0 & 0 & 1170 \\
\hline FR690946.1 & $10^{-109}$ & $\begin{array}{l}\text { Candidatus Thiomargarita nelsonii partial 16S rRNA } \\
\text { gene, isolate NAM057 }\end{array}$ & Giant sulfur bacterium & 0 & 0 & 1167 \\
\hline EU795103.1 & 0 & $\begin{array}{l}\text { Uncultured bacterium ARCTIC45_G_10 genomic } \\
\text { sequence }\end{array}$ & $?$ & 7 & 0 & 1004 \\
\hline
\end{tabular}




\begin{tabular}{|c|c|c|c|c|c|c|}
\hline F0203512.1 & $10^{-74}$ & $\begin{array}{l}\text { Oleispira antarctica strain RB-8, complete genome } \\
\text { sequence }\end{array}$ & $\begin{array}{l}\text { Hydrocarbonoclastic } \\
\text { aerobic bacterium }\end{array}$ & 0 & 0 & 957 \\
\hline HQ153940.1 & 0 & $\begin{array}{l}\text { Uncultured bacterium clone V1SC07b35 } 16 \mathrm{~S} \\
\text { ribosomal RNA gene, partial sequence }\end{array}$ & $\begin{array}{l}\text { Hydrothermal vent } \\
\text { microbial mats }\end{array}$ & 8 & 0 & 819 \\
\hline EU101262.1 & 0 & $\begin{array}{l}\text { Uncultured bacterium clone RS06101_B70 } \\
\text { ribosomal RNA gene, partial sequence }\end{array}$ & Sulfur-oxidizing & 0 & 0 & 778 \\
\hline NR_076671.1 & 0 & $\begin{array}{l}\text { Kangiella koreensis DSM } 16069 \text { strain DSM } 1606923 \mathrm{~S} \\
\text { ribosomal RNA, complete sequence }\end{array}$ & $\begin{array}{l}\text { Oceanospirillales free-living } \\
\text { bacterium }\end{array}$ & 3 & 0 & 589 \\
\hline NR_076212.1 & $210^{-131}$ & $\begin{array}{l}\text { Treponema denticola ATCC } 35405 \text { strain ATCC } 35405 \\
\text { 23S ribosomal RNA, complete sequence }\end{array}$ & $\begin{array}{l}\text { Periodontal disease } \\
\text { associate }\end{array}$ & 5 & 0 & 546 \\
\hline GU567978.1 & $610^{-93}$ & $\begin{array}{l}\text { Uncultured gamma proteobacterium HF0200_34B07 } \\
\text { genomic sequence }\end{array}$ & $?$ & 0 & 0 & 522 \\
\hline GU928698.1 & $910^{-90}$ & $\begin{array}{l}\text { Uncultured eukaryote clone F5K2Q4C04JA1DB } 28 \mathrm{~S} \\
\text { ribosomal RNA gene, partial sequence }\end{array}$ & $?$ & 1 & 0 & 521 \\
\hline FJ202296.1 & 0 & $\begin{array}{l}\text { Uncultured bacterium clone SGUS1039 16S ribosomal } \\
\text { RNA gene, partial sequence }\end{array}$ & $?$ & 1 & 0 & 521 \\
\hline HE610322.1 & $10^{-140}$ & $\begin{array}{l}\text { Uncultured Mycoplasmataceae bacterium partial } 16 \mathrm{~S} \\
\text { rRNA gene, clone 3-B9 }\end{array}$ & $\begin{array}{l}\text { Mud-crab intestinal } \\
\text { mollicute }\end{array}$ & 4 & 0 & 476 \\
\hline EF990727.1 & $410^{-116}$ & $\begin{array}{l}\text { Rhabditoides inermiformis strain SB328 } 28 \mathrm{~S} \text { large } \\
\text { subunit ribosomal RNA gene, partial sequence }\end{array}$ & $\begin{array}{l}\text { Nematodes living on } \\
\text { vegetation debris }\end{array}$ & 0 & 0 & 466 \\
\hline HE610322.1 & 0 & $\begin{array}{l}\text { Uncultured Mycoplasmataceae bacterium partial } 16 \mathrm{~S} \\
\text { rRNA gene, clone 3-B9 }\end{array}$ & $\begin{array}{l}\text { Mud-crab intestinal } \\
\text { mollicute }\end{array}$ & 3 & 0 & 464 \\
\hline NR_076858.1 & $10^{-58}$ & $\begin{array}{l}\text { Marinomonas mediterranea MMB-1 strain MMB-1 23S } \\
\text { ribosomal RNA, complete sequence }\end{array}$ & $\begin{array}{l}\text { Free-living melanogenic } \\
\text { bacterium }\end{array}$ & 0 & 0 & 460 \\
\hline NR_076770.1 & $10^{-144}$ & $\begin{array}{l}\text { Spirochaeta smaragdinae DSM } 11293 \text { strain DSM } \\
11293 \text { 23S ribosomal RNA, complete sequence }\end{array}$ & $\begin{array}{l}\text { Free-living thiosulfate and } \\
\text { sulfur reducer }\end{array}$ & 3 & 0 & 432 \\
\hline EU101262.1 & $210^{-169}$ & $\begin{array}{l}\text { Uncultured bacterium clone RS06101_B70 } \\
\text { ribosomal RNA gene, partial sequence }\end{array}$ & Sulfur-oxidizing & 1 & 0 & 381 \\
\hline NR_121913.1 & 0 & $\begin{array}{l}\begin{array}{l}\text { Desulfuromonas acetoxidans strain DSM } 684 \\
\text { ribosomal RNA, complete sequence }\end{array} \\
\end{array}$ & Anaerobic sulfur reducer & 3 & 0 & 380 \\
\hline EU101262.1 & 0 & $\begin{array}{l}\text { Uncultured bacterium clone RS06101_B70 } \\
\text { ribosomal RNA gene, partial sequence }\end{array}$ & Sulfur-oxidizing & 1 & 0 & 314 \\
\hline GU908489.1 & 0 & $\begin{array}{l}\text { Spiroplasma litorale 16S ribosomal RNA gene, partial } \\
\text { sequence; } 16 \mathrm{~S}-23 \mathrm{~S} \text { ribosomal RNA intergenic spacer, }\end{array}$ & $\begin{array}{l}\text { Dipteran-associated } \\
\text { mollicute }\end{array}$ & 4 & 1 & 311 \\
\hline
\end{tabular}




\begin{tabular}{|c|c|c|c|c|c|c|}
\hline & & $\begin{array}{l}\text { 23S ribosomal RNA gene, and 23S-5S ribosomal RNA } \\
\text { intergenic spacer, complete sequence; and } 5 \mathrm{~S} \\
\text { ribosomal RNA gene, partial sequence }\end{array}$ & & & & \\
\hline HM103460.1 & $410^{-93}$ & $\begin{array}{l}\text { Uncultured metazoan clone Ma29_1E_24 } \\
\text { ribosomal RNA gene, partial sequence }\end{array}$ & $?$ & 0 & 0 & 290 \\
\hline F0203512.1 & 0 & $\begin{array}{l}\text { Oleispira antarctica strain RB-8, complete genome } \\
\text { sequence }\end{array}$ & $\begin{array}{l}\text { Hydrocarbonoclastic } \\
\text { aerobic bacterium }\end{array}$ & 0 & 0 & 262 \\
\hline JN018328.1 & $310^{-56}$ & $\begin{array}{l}\text { Damon gracilis voucher MNHN-JAB38 } 28 \mathrm{~S} \text { ribosomal } \\
\text { RNA gene, partial sequence }\end{array}$ & Whip-spider & 0 & 0 & 230 \\
\hline NR_102551.1 & 0 & $\begin{array}{l}\text { Thioalkalivibrio nitratireducens DSM } 14787 \text { strain } \\
\text { DSM } 14787 \text { 23S ribosomal RNA, complete sequence }\end{array}$ & $\begin{array}{l}\text { Haloalkaliphilic } \\
\text { oxidizing bacterium }\end{array}$ & 1 & 2 & 208 \\
\hline DQ174761.1 & $210^{-73}$ & $\begin{array}{l}\text { Uncultured spirochete clone HaTB8 large subunit } \\
\text { ribosomal RNA gene, partial sequence }\end{array}$ & $\begin{array}{l}\text { Coral protistan agal } \\
\text { symbiont }\end{array}$ & 2 & 0 & 205 \\
\hline AJ879862.1 & $210-103$ & Uncultured organism 28S rRNA gene, clone ASt-53 & $?$ & 0 & 0 & 176 \\
\hline JN145195.1 & $210^{-81}$ & $\begin{array}{l}\text { Uncultured eukaryote clone NZAS-293 } 18 \mathrm{~S} \text { ribosomal } \\
\text { RNA gene, partial sequence }\end{array}$ & $?$ & 0 & 20 & 167 \\
\hline NR_076865.1 & $310^{-61}$ & $\begin{array}{l}\text { Desulfobacca acetoxidans DSM } 11109 \text { strain DSM } \\
11109 \text { 23S ribosomal RNA, complete sequence }\end{array}$ & $\begin{array}{l}\text { Deltaproteobacterium } \\
\text { Sulfate reducer }\end{array}$ & 0 & 0 & 138 \\
\hline GU245692.1 & $410^{-59}$ & $\begin{array}{l}\text { Krefftascaris sharpiloi isolate } 2 \text { 18S rRNA gene, partial } \\
\text { sequence; ITS } 1,5.8 \mathrm{~S} \text { rRNA gene, and ITS } 2 \text {, complete } \\
\text { sequence; and } 28 \mathrm{~S} \text { rRNA gene, partial sequence }\end{array}$ & Turtle parasite & 0 & 0 & 137 \\
\hline NR_103985.1 & $210^{-77}$ & $\begin{array}{l}\text { Spiroplasma chrysopicola DF-1 strain } \text { DF-1 23S } \\
\text { ribosomal RNA, complete sequence }\end{array}$ & $\begin{array}{l}\text { Dipteran-associated gut } \\
\text { mollicute }\end{array}$ & 1 & 0 & 116 \\
\hline
\end{tabular}


Figure 1




Figure 2

A



B

\section{LABER}

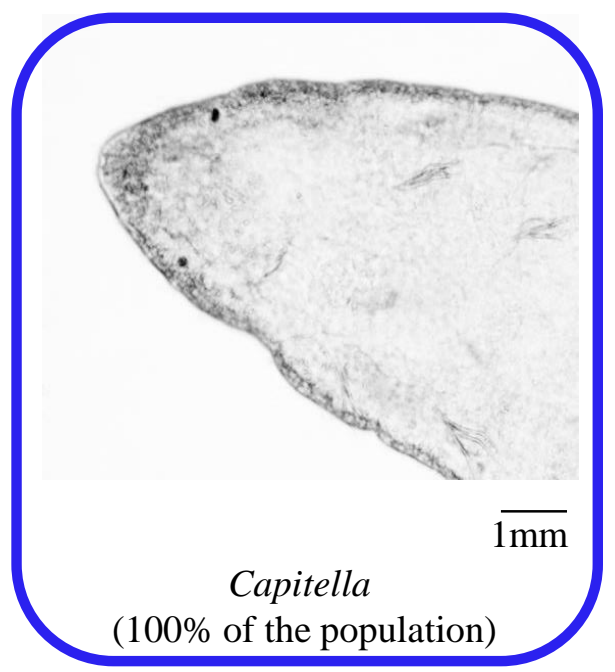

FPKM1
HARBOR



FPKM2



Epibionts

Epibiotic Capitella ( $20 \%$ of the population) 
Figure 3

Figure 4

Figure 5



0.020 
Figure 6




Figure 7

BioNJ 499 sites HKY 100 repl.




Figure 8




Click here to access/download

\section{Supplementary material for on-line publication only sup mat merge.pdf}




\section{Credit author statement}

Stéphane Hourdez: Provision of biological materials, data curation (RNAseq), writing the initial draft, data presentation, investigation, conceptualization. Céline Boidin-Wichlacz: Provision of biological materials, design of methodology, performing the experiments, data presentation, writing the initial draft and editing. Didier Jollivet: Genetic analyses, conceptualization, writing the initial draft, editing, and review of the published work. François Massol: Statistical analyses, creation of models, writing the initial draft, review of the published work. Maria Claudia Rayol: Provision of biological materials, performing the experiments, data collection. Renato Bruno: Provision of biological materials. Daniela Zeppilli: Provision of biological materials, critical review. Frederic Thomas: Critical review, commentary. Ludovic Lesven: Design of methodology, performing the experiments, data presentation, writing the initial draft. Gabriel Billon: conceptualization, writing the initial draft, editing, and review of the published work. Sebastien Duperron: Design of methodology, conceptualization, performing the experiments, data presentation, writing the initial draft, review and editing of the published work- Aurélie Tasiemski: Provision of biological materials, performing the experiments, data presentation, visualization, writing the initial draft, review and final editing of the published work, conceptualization, supervision and project administration. 


\section{Declaration of interests}

$\bigotimes$ The authors declare that they have no known competing financial interests or personal relationships that could have appeared to influence the work reported in this paper.

$\square$ The authors declare the following financial interests/personal relationships which may be considered as potential competing interests:



